Prepared in cooperation with the South Carolina Department of Transportation

\title{
A Pier-Scour Database: 2,427 Field and Laboratory Measurements of Pier Scour
}

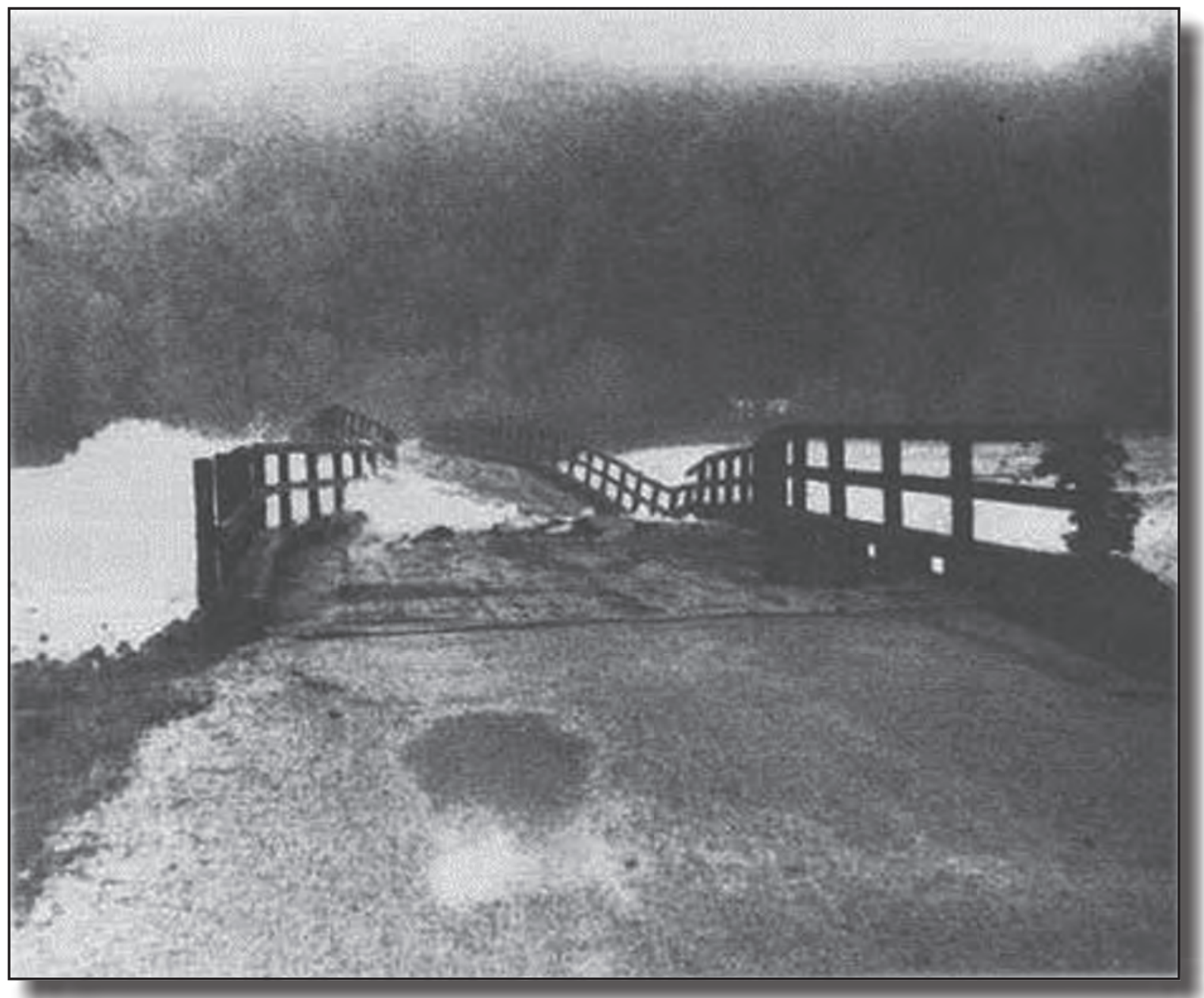

Data Series 845 
Cover. Failure of the State Highway 50 bridge crossing the Tallapoosa River near Tallassee, Alabama, April 14, 1979. Photograph courtesy of H. H. Weldon, Eclectic, Alabama, at http://md.water.usgs.gov/publications/wsp-2375/al/. 


\section{A Pier-Scour Database: 2,427 Field and Laboratory Measurements of Pier Scour}

By Stephen T. Benedict and Andral W. Caldwell

Prepared in cooperation with the South Carolina Department of Transportation

Data Series 845

U.S. Department of the Interior

U.S. Geological Survey 


\title{
U.S. Department of the Interior SALLY JEWELL, Secretary
}

\section{U.S. Geological Survey Suzette M. Kimball, Acting Director}

\author{
U.S. Geological Survey, Reston, Virginia: 2014
}

For more information on the USGS - the Federal source for science about the Earth, its natural and living resources, natural hazards, and the environment, visit http://www.usgs.gov or call 1-888-ASK-USGS.

For an overview of USGS information products, including maps, imagery, and publications, visit http://www.usgs.gov/pubprod

To order this and other USGS information products, visit http://store.usgs.gov

Any use of trade, firm, or product names is for descriptive purposes only and does not imply endorsement by the U.S. Government.

Although this information product, for the most part, is in the public domain, it also may contain copyrighted materials as noted in the text. Permission to reproduce copyrighted items must be secured from the copyright owner.

Suggested citation:

Benedict, S.T., and Caldwell, A.W., 2014, A pier-scour database-2,427 field and laboratory measurements of pier scour: U.S. Geological Survey Data Series 845, 22 p., http://dx.doi.org/10.3133/ds845.

ISSN 2327-638X (online) 


\section{Acknowledgments}

The 2014 USGS Pier-Scour Database (PSDb-2014) includes 2,427 laboratory and field measurements of pier scour. These data represent an extensive investment of time and effort by many investigators to collect, document, and analyze those data. These investigators have made individual and collective contributions to the advancement of the current understanding of pier scour, and the authors of this report acknowledge the investigators' contributions. The authors also would like to acknowledge Mr. R. Wayne Corley, SCDOT Hydraulic Design Manager, and Mr. Jess D. Weaver, USGS Southeast Area Regional Executive, whose support made this investigation and report possible. 


\section{Contents}

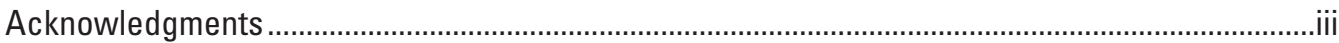

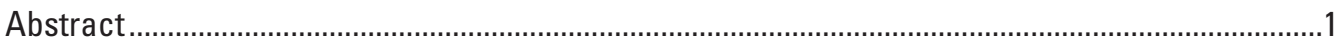

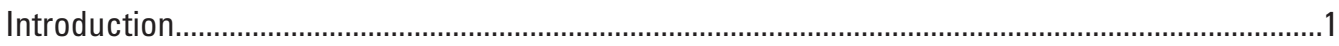

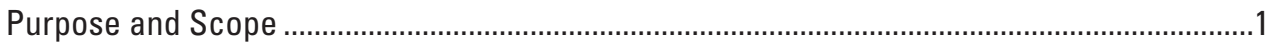

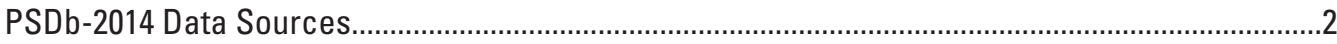

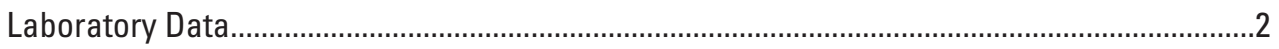

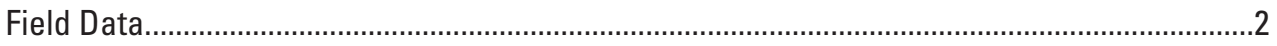

Previous Compilations of Field Data .................................................................................

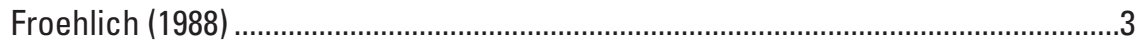

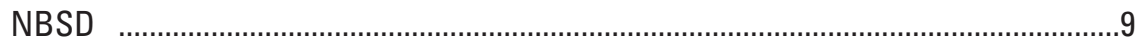

Sheppard and Others (2011) ................................................................................

Overview of Field Data by State and Country ..............................................................

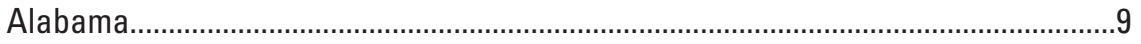

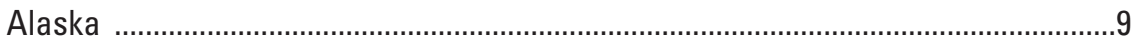

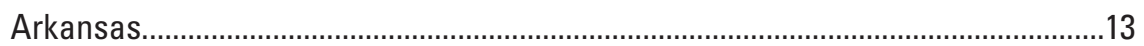

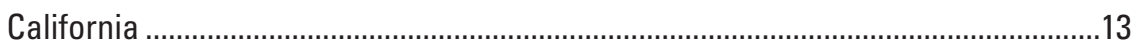

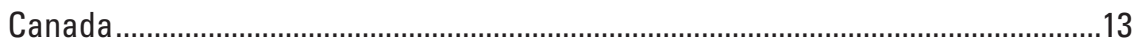

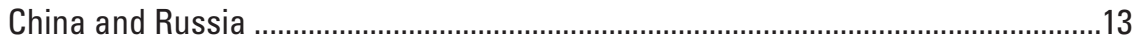

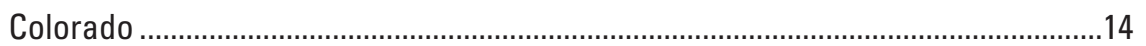

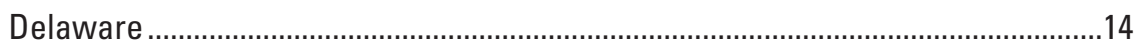

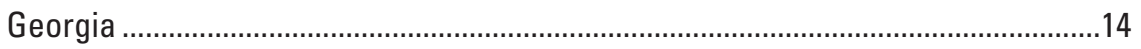

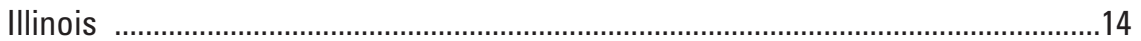

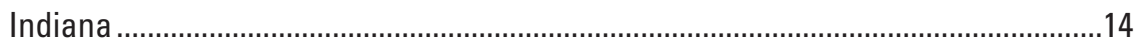

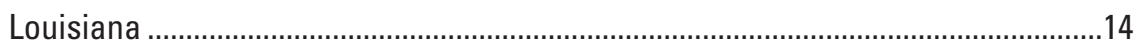

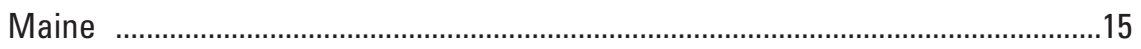

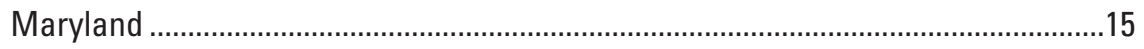

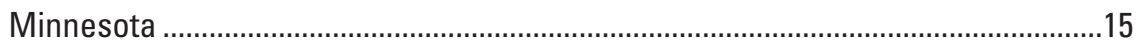

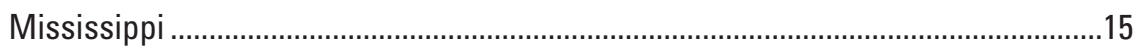

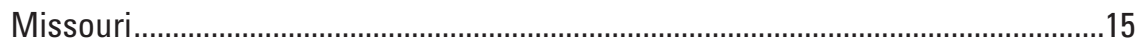

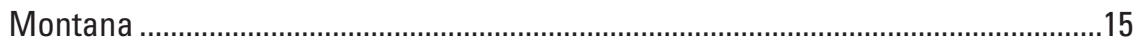

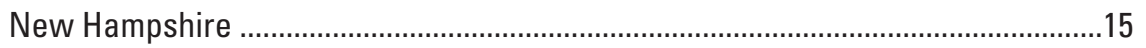

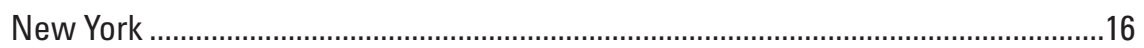

Ohio

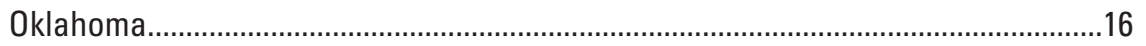

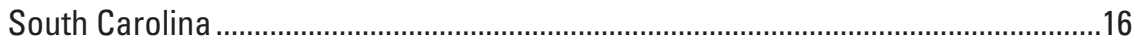

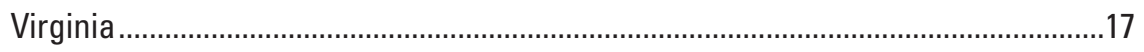

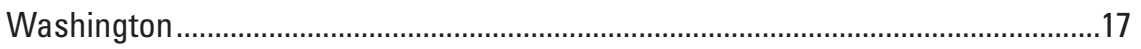




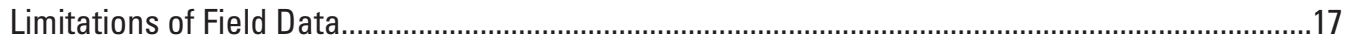

Equilibrium Scour Depth ........................................................................................................ 18

Measurement Technique......................................................................................................... 18

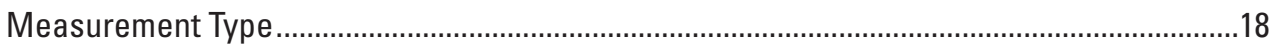

Determination of Hydraulic Properties .......................................................................................18

Sediment Characteristics ...................................................................................................... 18

Pier Width Normal to Flow .................................................................................................... 19

Real-Time Scour Evaluation ..................................................................................................19

Additional Scour Investigations ........................................................................................... 19

Future Assessment Criteria .............................................................................................. 19

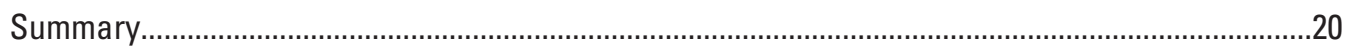

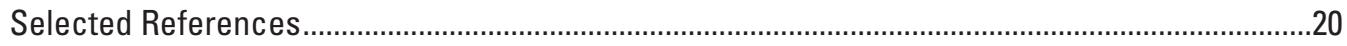

\section{Tables}

1. Sources for laboratory data compiled in the PSDb-2014 ...................................................2

2. Type of laboratory data included in the PSDb-2014 for each laboratory

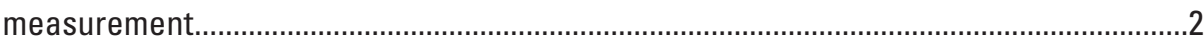

3. Range of selected variables associated with the laboratory data in the

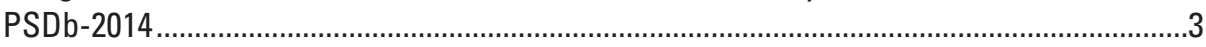

4. Sources for field data compiled in the PSDb-2014 .............................................................4

5. Range of selected variables associated with the field data compiled in the

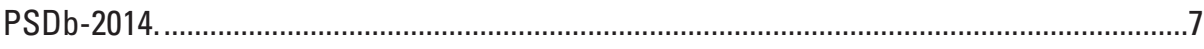

6. Type of field data included in the PSDb-2014 for each field measurement......................8

7. Range of selected variables associated with the field data compiled in the PSDb-2014 grouped by State or Country ........................................................................ 10 


\section{Conversion Factors}

Inch/Pound to SI

\begin{tabular}{lcl}
\hline \multicolumn{1}{c}{ Multiply } & By & \multicolumn{1}{c}{ To obtain } \\
\hline foot $(\mathrm{ft})$ & Length & meter $(\mathrm{m})$ \\
mile $(\mathrm{mi})$ & 0.3048 & kilometer $(\mathrm{km})$ \\
\hline & 1.609 & \\
\hline square mile $\left(\mathrm{mi}^{2}\right)$ & Area & square kilometer $\left(\mathrm{km}^{2}\right)$ \\
\hline & 2.590 & \\
\hline foot per second $(\mathrm{ft} / \mathrm{s})$ & Flow rate & meter per second $(\mathrm{m} / \mathrm{s})$ \\
\hline
\end{tabular}

\section{Acronyms and Abbreviations}

$\begin{array}{ll}\text { BSDMS } & \text { Bridge-Scour Data Management System } \\ \text { GPR } & \text { Ground Penetrating Radar } \\ \text { HEC-18 } & \text { Hydraulic Engineering Circular No. 18 } \\ \text { NBSD } & \text { National Bridge Scour Database } \\ \text { PSDb-2014 } & \text { 2014 USGS Pier-Scour Database } \\ \text { SCDOT } & \text { South Carolina Department of Transportation } \\ \text { USGS } & \text { U.S. Geological Survey } \\ \text { WSPRO } & \text { Water Surface Profile computation model }\end{array}$




\title{
A Pier-Scour Database: 2,427 Field and Laboratory Measurements of Pier Scour
}

\author{
By Stephen T. Benedict and Andral W. Caldwell
}

\begin{abstract}
The U.S. Geological Survey conducted a literature review to identify potential sources of published pier-scour data, and selected data were compiled into a digital spreadsheet called the 2014 USGS Pier-Scour Database (PSDb-2014) consisting of 569 laboratory and 1,858 field measurements. These data encompass a wide range of laboratory and field conditions and represent field data from 23 States within the United States and from 6 other countries. The digital spreadsheet is available on the Internet (http://pubs.usgs.gov/ds/845) and offers a valuable resource to engineers and researchers seeking to understand pier-scour relations in the laboratory and field.
\end{abstract}

\section{Introduction}

The U.S. Geological Survey (USGS), in cooperation with the South Carolina Department of Transportation (SCDOT), collected 335 measurements of historical pier scour in South Carolina (Benedict and Caldwell, 2006; Benedict and Caldwell, 2009), with nominal pier widths ranging from 0.8 to 9 feet ( $\mathrm{ft}$ ). These data were used to develop field-derived pier-scour envelope curves that reflect the upper bound of pier scour with respect to pier width for bridges in South Carolina. To expand upon this previous work, the USGS and SCDOT initiated a subsequent cooperative investigation to combine the South Carolina data with pier-scour data from other sources and evaluate upper-bound relations within this larger dataset. A literature review was conducted to identify potential sources of pier-scour data, and selected data were compiled into a database consisting of 2,427 measurements of pier scour (569 laboratory and 1,858 field measurements). These data substantially extended the nominal pier-width range to 0.05 to $64 \mathrm{ft}$. The spatial extent of the database increased to include data from 23 States within the United States and 6 other countries, providing a means to evaluate the upper-bound of pier scour with a significantly larger database.

Of the 1,858 field measurements compiled in this study, 78 percent (1,444 measurements) were associated with data collected or compiled by the USGS; therefore, the database, consisting of the field and laboratory data and designated the
"2014 USGS Pier-Scour Database," will be referred to as the PSDb-2014 for the remainder of this report. While a portion of the field data in the PSDb-2014 (480 measurements) was previously published digitally in the National Bridge Scour Database (NBSD; U.S. Geological Survey, 2001), most of the laboratory and field data in the PSDb-2014 were not previously available in a readily accessible digital database. Because the digital database offers a valuable resource to engineers and researchers seeking to understand pier-scour relations in the laboratory and field, it was deemed important to publish the compiled data in a digital database for use by others.

While limitations are associated with the field data in the PSDb-2014, the strengths of this database include (1) the large number of measurements $(1,858),(2)$ the diversity of site characteristics (table 3), and (3) inclusion of the most thoroughly documented and screened field data currently (2014) available (USGS, 2001; Holnbeck, 2011; Sheppard and others, 2011). These field data, in conjunction with the 569 laboratory measurements, offer a valuable resource to researchers and practitioners that can be used in various ways including, but not limited to, (1) evaluating the range of the dimensionless parameters used in the laboratory with the range of those determined in the field, (2) confirming and extending the relations observed in the laboratory data, (3) evaluating the influence of selected variables on pier-scour depth, (4) providing an assessment of the performance of selected scour-prediction equations, (5) identifying ways to improve the performance of selected scour-prediction equations, (6) developing new scourprediction methods through various analysis, (7) defining upper-bound envelopes of pier-scour depth that can provide guidance to practitioners, and (8) making site comparisons using selected field data from the database that have similar characteristics to a site of interest to gain insights into scour potential.

\section{Purpose and Scope}

The purpose of this report is to briefly describe (1) the laboratory and field data compiled in the PSDb-2014, (2) the digital spreadsheet that contains the PSDb-2014, (3) limitations of the data, and (4) potential uses of the data. The digital spreadsheet that contains the PSDb-2014 can be downloaded from http://pubs.usgs.gov/ds/845. 


\section{PSDb-2014 Data Sources}

The PSDb-2014 consists of 569 laboratory measurements and 1,858 field measurements. The sources of the laboratory and field measurements are described in the following sections of the report.

\section{Laboratory Data}

The laboratory data in the PSDb-2014 consist of 569 measurements taken from 17 previous investigations (table 1) that were compiled by Sheppard and others (2011). Through a screening process that included data review and statistical analysis, Sheppard and others (2011) identified 441 of the laboratory measurements that approximated equilibrium scour depths and used that data in their investigation of pier scour. While the remaining 128 measurements may not fully reflect equilibrium scour depths, the measurements still can be useful in formulating certain relations, such as envelope curves, and confirming basic relations and therefore were included in the PSDb-2014. Some of the laboratory measurements compiled by Sheppard and others (2011) are of historical interest. In particular, many of the data collected by Chabert and Engeldinger (1956) and Shen and others (1969) were used to develop the original Hydraulic Engineering Circular No. 18 (HEC-18) pier-scour equation (Richardson and others, 1991). The laboratory data included in the PSDb-2014 were taken from Sheppard and others (2011), and a description of the data is listed in table 2. Table 3 provides the range of selected variables associated with the laboratory data. The 441 screened measurements used by Sheppard and others (2011) were identified in the PSDb-2014 with values of 1 or 2 assigned to the Sheppard and others (2011) usage code to provide a means to extract those data.

\section{Field Data}

The field data in the PSDb-2014 consist of 1,858 measurements taken from 32 publications (table 4 ) and collected in 23 States within the United States and 6 other countries.

The compiled data include a wide range of stream gradients, drainage areas, sediment sizes, flow depths, flow velocities, and pier sizes (table 5), providing a diverse database for assessing pier-scour relations. The types of field data included in the database are listed in table 6 along with brief descriptions of each data type. The data compiled in the PSDb-2014 were taken directly from the cited sources. Some exceptions to this include computations of the pier width normal to flow (described in the "Limitations in Field Data" section) when not provided in the original source and the approach flow depth associated with the Hayes (1996) data. Most of the data published in the cited sources (table 4) were included in the PSDb-2014; however, some measurements were excluded because of missing data, questionable data, or unusual site
Table 1. Sources for laboratory data compiled in the PSDb-2014.

\begin{tabular}{lc}
\hline \multicolumn{1}{c}{ aSource of data } & $\begin{array}{c}\text { Number of } \\
\text { measurements } \\
\text { from the source }\end{array}$ \\
\hline Chabert and Engeldinger (1956) & 93 \\
Chee (1982) & 37 \\
Chiew (1984) & 101 \\
Coleman (unpublished personal commun., & \\
as sited in Sheppard and others, 2011) & 6 \\
Dey and others (1995) & 18 \\
Ettema (1976) & 19 \\
Ettema (1980) & 97 \\
Ettema and others (2006) & 6 \\
Graf (1995) & 3 \\
Jain and Fischer (1979) & 34 \\
Jones (unpublished personal commun., as & 17 \\
sited in Sheppard and others, 2011) & 17 \\
Melville (1997) & 27 \\
Melville and Chiew (1999) & 23 \\
Shen and others (1969) & 14 \\
Sheppard and others (2004) & 24 \\
Sheppard and Miller (2006) & 33 \\
Yanmaz and Altinbilek (1991) & \\
\hline
\end{tabular}

${ }^{a}$ These data were taken from Sheppard and others (2011) and can be viewed at: http://www.trb.org/main/blurbs/164161.aspx

Table 2. Type of laboratory data included in the PSDb-2014 for each laboratory measurement.

[N/A, not applicable]

\begin{tabular}{lcl}
\hline \multicolumn{1}{c}{ Type of data } & $\begin{array}{c}\text { Symbol used in } \\
\text { database }\end{array}$ & \multicolumn{1}{c}{ Units } \\
\hline Pier width normal to flow & $b_{n}$ & Feet \\
Approach flow velocity & $V_{o}$ & Feet per second \\
Sediment critical velocity & $V_{c}$ & Feet per second \\
Approach flow depth & $y_{o}$ & Feet \\
Median grain size & $D 50$ & Millimeter \\
Sediment gradation & $\sigma \mathrm{g}$ & Dimensionless \\
Length of experimental test & N/A & Minutes \\
Measured pier-scour depth & $y_{s}$ & Feet \\
Sheppard and others (2011) & 1-Used; & Dimensionless \\
usage code & 2-Used in Wide & \\
& Pier Analysis; & \\
& 0-Not Used & \\
\hline
\end{tabular}


Table 3. Range of selected variables associated with the laboratory data in the PSDb-2014.

[ft, foot; $\mathrm{ft} / \mathrm{s}$, foot per second; $\mathrm{mm}$, millimeter]

\begin{tabular}{|c|c|c|c|c|c|c|c|c|}
\hline $\begin{array}{l}\text { Range } \\
\text { value }\end{array}$ & $\begin{array}{c}\text { Pier width } \\
\text { normal to } \\
\text { flow } \\
- \\
b_{n} \\
\text { (ft) }\end{array}$ & $\begin{array}{c}\text { Approach } \\
\text { flow } \\
\text { velocity } \\
\bar{v} \\
V_{o} \\
\text { (ft/s) }\end{array}$ & $\begin{array}{c}\text { Approach } \\
\text { flow } \\
\text { depth } \\
- \\
y_{o} \\
\text { (ft) }\end{array}$ & $\begin{array}{c}\text { Median } \\
\text { grain } \\
\text { size } \\
- \\
D 50 \\
(\mathrm{~mm})\end{array}$ & $\begin{array}{c}\text { Measured } \\
\text { pier-scour } \\
\text { depth } \\
- \\
y_{s} \\
\text { (ft) }\end{array}$ & $\begin{array}{c}\text { Relative } \\
\text { flow } \\
\text { depth } \\
-y_{d} / b_{n}\end{array}$ & $\begin{array}{c}\begin{array}{c}\text { Relative } \\
\text { scour } \\
\text { depth } \\
- \\
y_{s} / b_{n}\end{array}\end{array}$ & $\begin{array}{c}\text { Relative } \\
\text { sediment } \\
\text { coarseness } \\
- \\
b_{H} / D 50\end{array}$ \\
\hline \multicolumn{9}{|c|}{$\begin{array}{l}\text { Laboratory data } \\
\text { compiled by Sheppard and others, 2011) }\end{array}$} \\
\hline Minimum & 0.1 & 0.5 & 0.1 & 0.2 & 0.0 & 0.1 & 0.1 & 3.7 \\
\hline Median & 0.2 & 1.4 & 0.6 & 0.8 & 0.3 & 2.7 & 1.5 & 79.8 \\
\hline Maximum & 3.0 & 7.1 & 6.2 & 7.8 & 4.6 & 21.0 & 3.1 & $4,159.2$ \\
\hline
\end{tabular}

conditions. The quality of a given field measurement will vary with the techniques used to collect the data and the hydraulic conditions associated with the measurement. To assist in evaluating measurement quality, selected information describing data-collection techniques for each pier-scour measurement was included in the database, when readily available. This qualitative information includes the measurement technique used to collect the scour data, the measurement-type category, and the method for determining the hydraulic properties associated with the scour measurement. A description of this qualitative information is included in the "Limitations of the Field Data" section. For many pier-scour measurements, the cited source provided adequate information to determine this qualitative information. In some cases, however, the cited source provided limited or no information, and judgment was used to define these qualitative data. A review of the data sources is advised for further understanding about the field data included in the PSDb-2014 and any associated limitations.

\section{Previous Compilations of Field Data}

The PSDb-2014 incorporates compiled pier-scour data from three previous investigations including Froehlich (1988), NBSD (U.S. Geological Survey, 2001), and Sheppard and others (2011). Because of their historical significance, data associated with these studies were included and identified in the PSDb-2014 so that they could be extracted and used to confirm and (or) expand the previous findings. Data from these three sources frequently overlapped, and care was taken in the development of the PSDb-2014 to remove duplicate measurements while still identifying measurements that were included in more than one of these studies. For example, field measurements originally published in Norman (1975) were included in Froehlich (1988), NBSD, and Sheppard and others (2011), and all four sources were identified for these data in the PSDb-2014.

\section{Froehlich (1988)}

Froehlich (1988) compiled 83 field measurements of pier scour and developed a predictive equation based on those data. The data were compiled from various sources and included 68 measurements from the United States (Alaska, Colorado, Louisiana, and Mississippi) and 15 from other countries (Canada, New Zealand, Nigeria, and Yugoslavia). Froehlich (1988) notes that the measurements were collected during sustained high flows using various measurement methods including fathometers, sounding weights, and sounding rods. Much of the data from the United States (46 measurements) also were included in the NBSD, and comparison of these common data were made to assure consistency between the two databases. Minor discrepancies between some of the common Colorado data from the NBSD and Froehlich (1988) were identified, and preference was given to the NBSD data. Comments in the PSDb-2014 spreadsheet cells noted the values published in Froehlich (1988) when they differed from the NBSD data. All 83 measurements from Froehlich (1988) were included in the PSDb-2014. Additional information describing the data compiled by Froehlich (1988) can be found in Froehlich (1988) and the original sources he cites, some of which can be accessed online (table 4). 


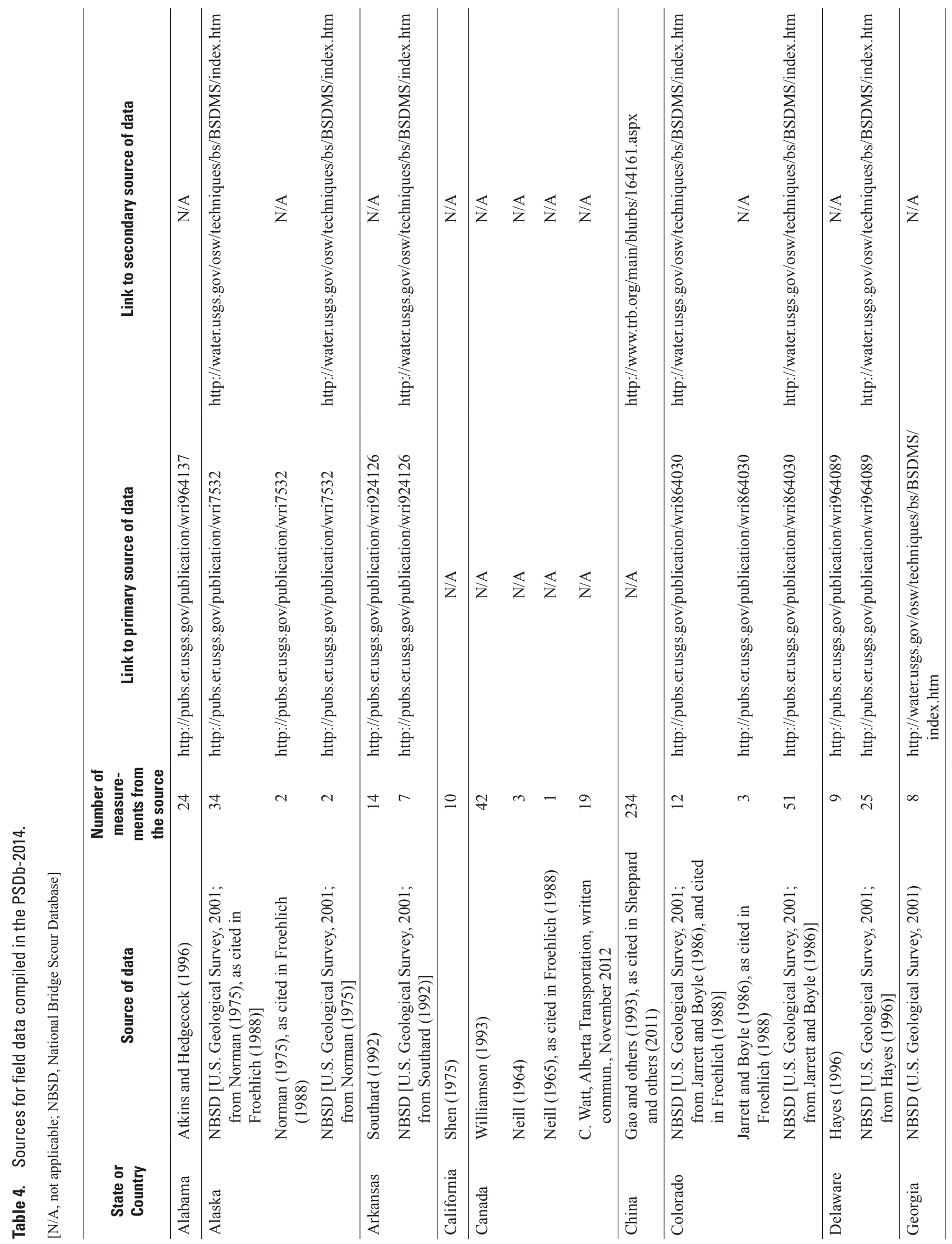




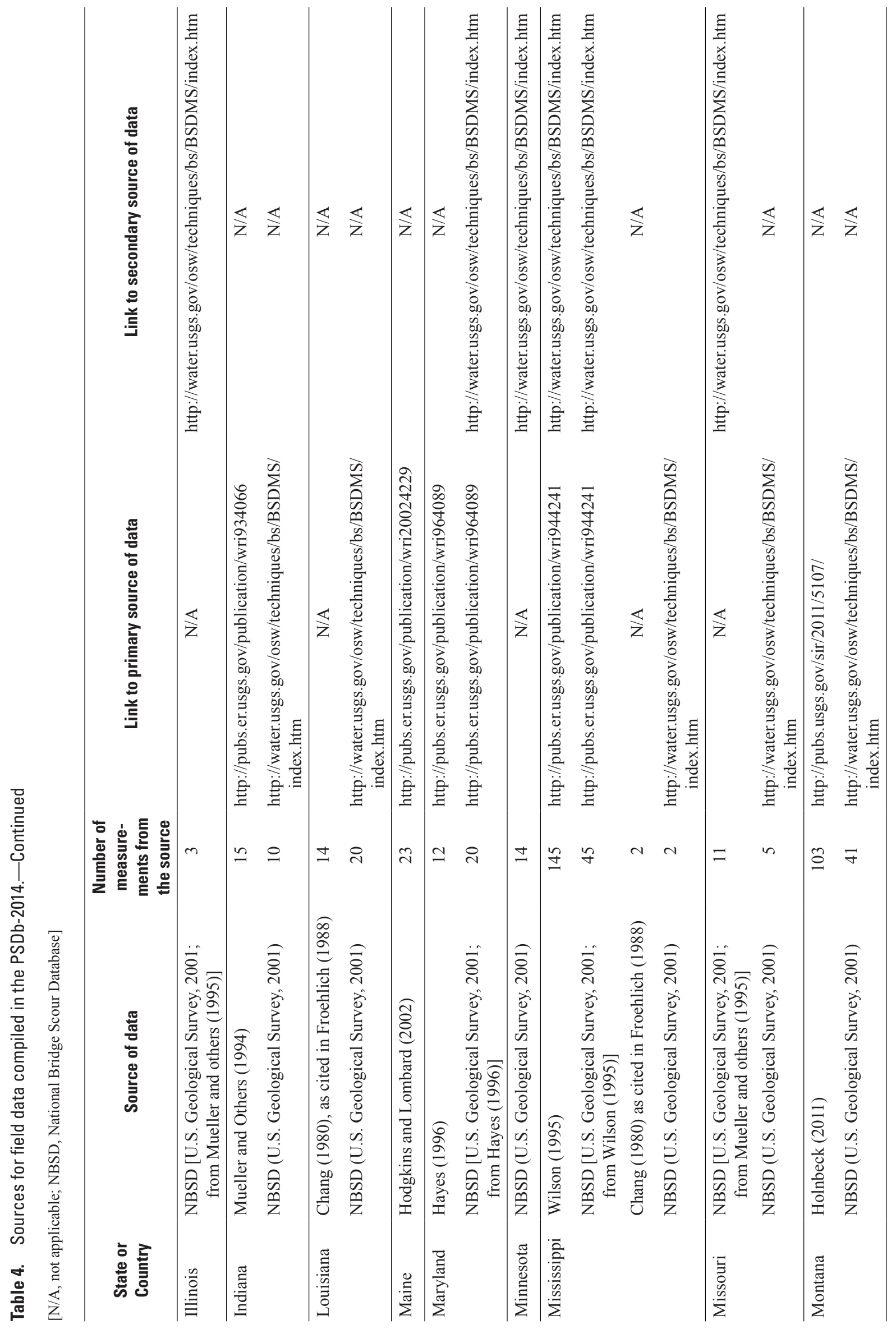




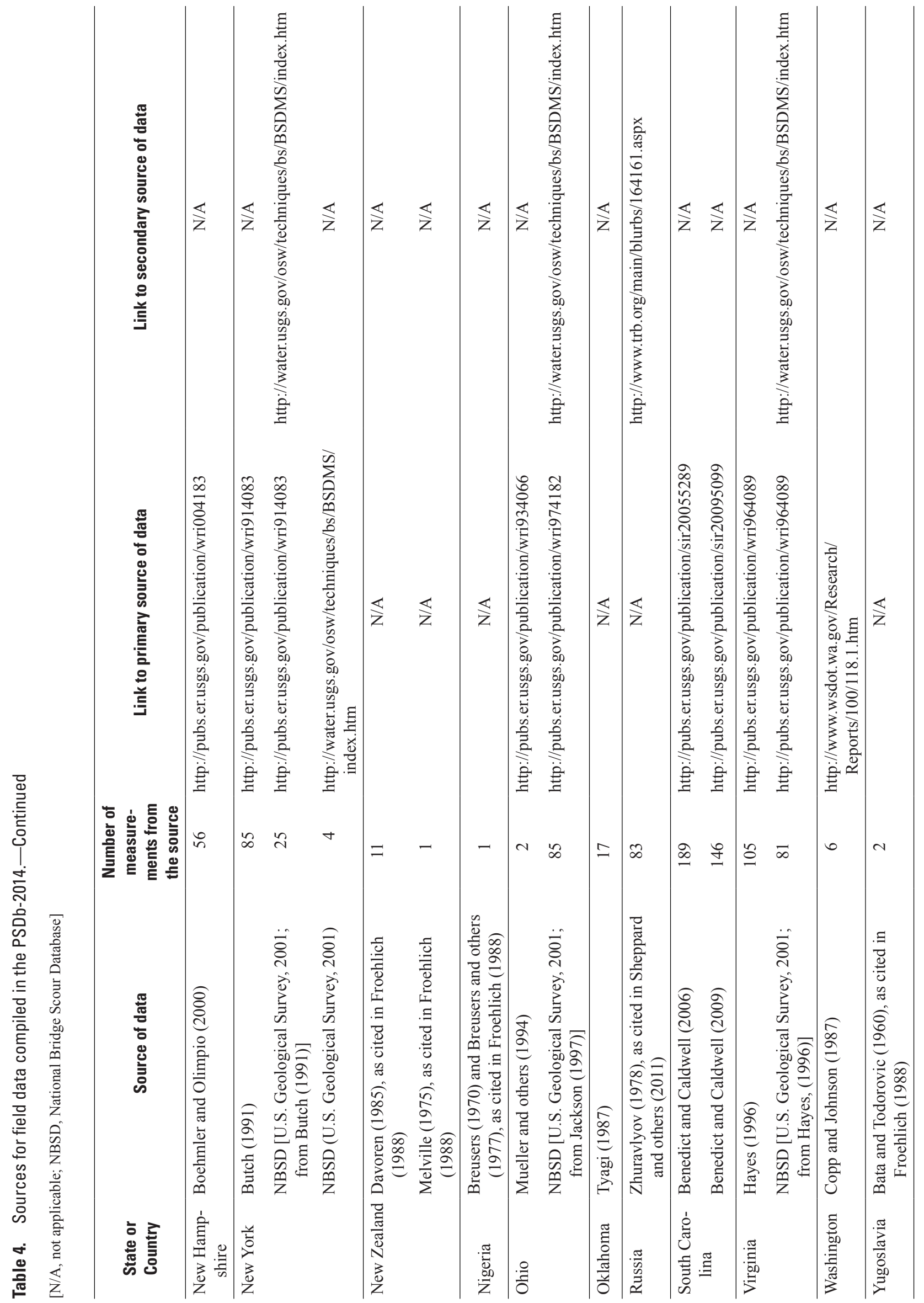


Table 5. Range of selected variables associated with the field data compiled in the PSDb-2014.

[mi², square miles; ft, foot; $\mathrm{ft} / \mathrm{s}$, foot per second; mm, millimeter]

\begin{tabular}{|c|c|c|c|c|c|c|c|c|c|c|}
\hline $\begin{array}{l}\text { Range } \\
\text { value }\end{array}$ & $\begin{array}{c}\text { Drainage } \\
\text { area } \\
- \\
\left(\mathrm{mi}^{2}\right)\end{array}$ & $\begin{array}{c}\text { Stream } \\
\text { slope } \\
-\overline{f t / f t})\end{array}$ & $\begin{array}{c}\text { Pier } \\
\text { width } \\
\text { normal to } \\
\text { flow } \\
\bar{b} \\
\text { (ft) }\end{array}$ & $\begin{array}{c}\text { Approach } \\
\text { flow } \\
\text { velocity } \\
- \\
V_{o} \\
(\mathrm{ft} / \mathrm{s})\end{array}$ & $\begin{array}{c}\text { Approach } \\
\text { flow } \\
\text { depth } \\
- \\
y_{o} \\
(\mathrm{ft})\end{array}$ & $\begin{array}{c}\text { Median } \\
\text { grain } \\
\text { size } \\
- \\
D 50 \\
(\mathrm{~mm})\end{array}$ & $\begin{array}{c}\text { Measured } \\
\text { pier-scour } \\
\text { depth } \\
- \\
y_{s} \\
(\mathrm{ft})\end{array}$ & $\begin{array}{c}\text { Relative } \\
\text { flow } \\
\text { depth } \\
- \\
y_{\delta} / b_{n}\end{array}$ & $\begin{array}{c}\text { Relative } \\
\text { scour } \\
\text { depth } \\
- \\
y_{s} / b_{n}\end{array}$ & $\begin{array}{c}\text { Relative } \\
\text { sediment } \\
\text { coarseness } \\
- \\
b_{n} / D 50\end{array}$ \\
\hline Minimum & $3.13^{\mathrm{a}}$ & $0.00007^{b}$ & 0.7 & $0.0^{c}$ & $0.0^{\mathrm{c}}$ & $0.001^{\mathrm{d}}$ & 0.0 & $0.0^{\mathrm{e}}$ & 0.0 & $5.7^{\mathrm{e}}$ \\
\hline Median & $1,081^{\mathrm{a}}$ & $0.00053^{b}$ & 4.9 & $4.20^{\mathrm{c}}$ & $9.8^{\mathrm{c}}$ & $0.9^{\mathrm{d}}$ & 2.3 & $2.1^{\mathrm{e}}$ & 0.5 & $1048^{\mathrm{e}}$ \\
\hline Maximum & $708,600^{a}$ & $0.02^{b}$ & 94.2 & $18.0^{\mathrm{c}}$ & $73.9^{c}$ & $228.6^{d}$ & 34.1 & $26.3^{\mathrm{e}}$ & 5.4 & $1,840,000^{\mathrm{e}}$ \\
\hline \multicolumn{11}{|c|}{$\begin{array}{c}\text { Screened Field Data } \\
\text { (727 measurements-Subset of PSDb-2014 previously screened by Sheppard and others, 2011) }\end{array}$} \\
\hline Maximum & $708,600^{f}$ & $0.007^{\mathrm{f}}$ & 55.3 & 15.4 & 73.9 & 108.0 & 25.6 & 9.6 & 1.8 & 65,100 \\
\hline
\end{tabular}

${ }^{a}$ Five hundred fifty-six measurements have missing drainage area.

${ }^{\mathrm{b}}$ Seven hundred seventy-five measurements have missing stream slope.

${ }^{c}$ Thirty-four measurements have missing flow velocity or depth.

${ }^{\mathrm{d}}$ Seventy-two measurements have missing median grain size.

${ }^{\mathrm{e}}$ Measurements with missing flow depth and (or) grain size data excluded.

${ }^{\mathrm{f}}$ Drainage area and stream slope missing for the measurements. 
Table 6. Type of field data included in the PSDb-2014 for each field measurement.

[N/A, not applicable]

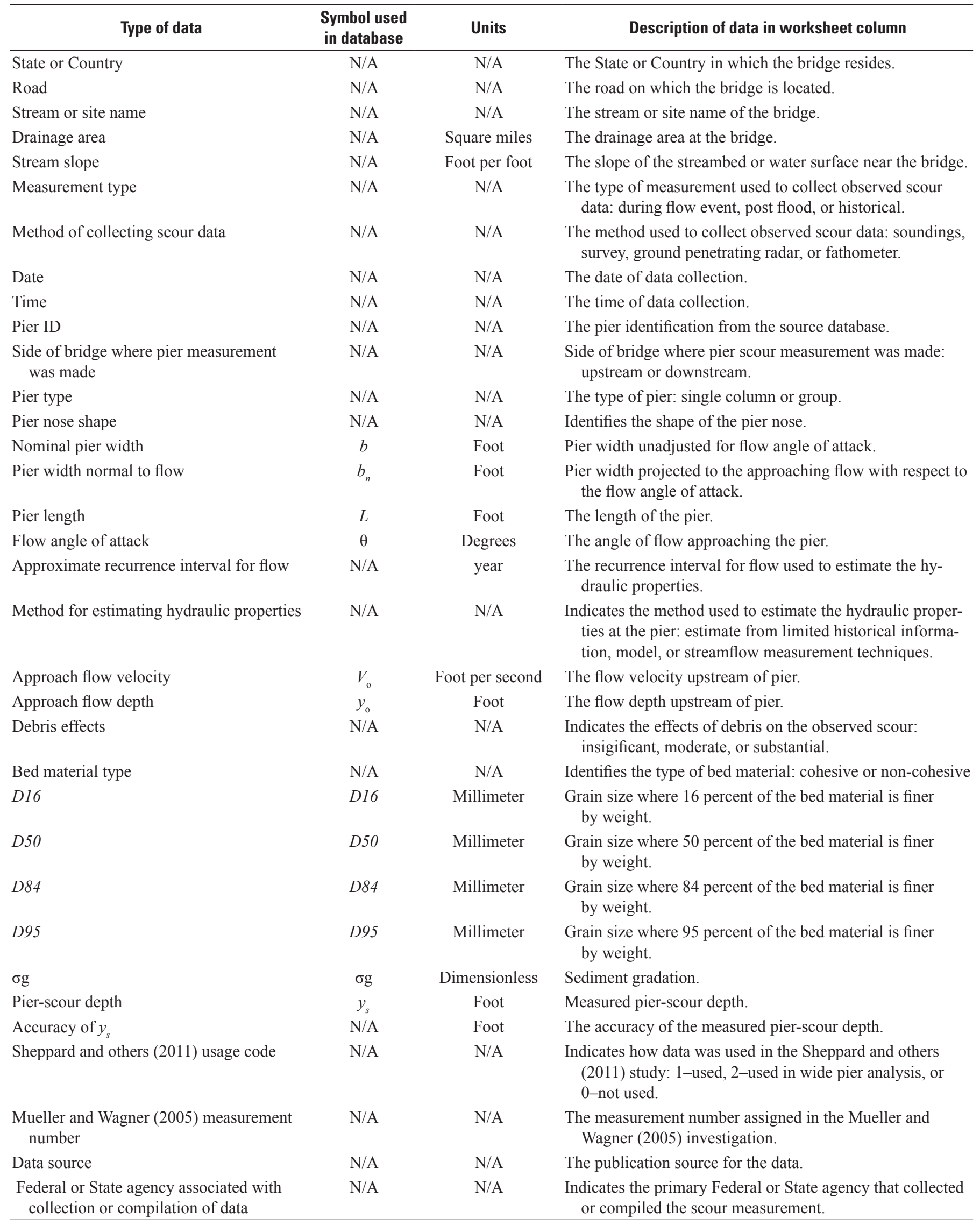




\section{NBSD}

The NBSD (U.S. Geological Survey, 2001) was developed by the USGS in cooperation with the Federal Highway Administration, the National Cooperative Highway Research Program, and the University of Louisville, Department of Civil Engineering, and includes field measurements of pier, abutment, and contraction scour collected from various locations within the United States. Most of the data in the NBSD were compiled from previous scour investigations conducted by the USGS. The precursor to the NBSD was the BridgeScour Data Management System (BSDMS; Landers and others, 1996), which was a Fortran-based computer program developed to store and manage field measurements of scour. The BSDMS was later converted to a Microsoft Access database to provide a more accessible format that could be served on the Internet (Mueller and Wagner, 2005; U.S. Geological Survey, 2001). The converted database was renamed the USGS National Bridge Scour Database, or NBSD. The NBSD contains more than 200 site and measurement attributes for each scour measurement including the channel geometry, flow hydraulics, hydrology, sediment, geomorphic setting, location, and bridge specifications (Mueller and Wagner, 2005), thus providing the most thoroughly documented pier-scour database to date. The NBSD included 508 field measurements in an online spreadsheet. Twenty-eight of these measurements were removed because of data limitations (see "Montana" report section), and the remaining 480 were included in the PSDb-2014. Additional information about the NBSD data can be found in Landers and others (1996), Mueller and Wagner (2005), and the NBSD (U.S. Geological Survey, 2001; table 4).

\section{Sheppard and Others (2011)}

Sheppard and others (2011) reviewed 943 field measurements of pier scour and selected 791 measurements for their investigation of scour at wide piers. The selected data included 83 measurements from Russia (Zhuravlyov, 1978), 65 measurements from Froehlich (1988) as described previously, 234 measurements from China (Gao and others, 1993), and 409 measurements from Mueller and Wagner (2005). A description of the data from China and Russia can be found in the "China and Russia" report section. The Mueller and Wagner (2005) data were originally published in the NBSD, and the data from the NBSD were used to represent the Mueller and Wagner (2005) data within the PSDb-2014. The measurement numbers from Mueller and Wagner (2005) were included in the PSDb-2014 to provide a means to identify these data. Twenty-one of the Mueller and Wagner (2005) measurements were removed because of data limitations (see "Montana" report section), and the remaining 770 selected measurements from Sheppard and others (2011) were included in the PSDb-2014. A data column in the PSDb-2014 identifies measurements associated with the Sheppard and others (2011) investigation. Because 43 of the Froehlich (1988) measurements included in the Sheppard and others (2011) study were duplicated in the Mueller and Wagner (2005) measurements, only 727 measurements in the PSDb-2014 are identified with the Sheppard and others (2011) study. Additional information about this data can be found in Sheppard and others (2011) and accessed online (table 4).

\section{Overview of Field Data by State and Country}

The field measurements included in the PSDb-2014 represent data collected in 23 States and 6 countries (table 7). Much of the field data (about 75 percent) were collected in field investigations initiated and managed at the state or provincial level (18 States and 1 province). In most cases, the state investigations were cooperative efforts between the local USGS Water Science Centers and the respective state Departments of Transportation. Because a large portion of the data is associated with state or provincial investigations, the field-data overview is presented by state, province, or country where the data were collected. Limited data from Nigeria, New Zealand, and Yugoslavia were included in the Froehlich (1988) database, as described previously, and are not included in this section. Internet addresses for many of the publications that document the various field investigations are provided in this report (table 4), and review of these sources is advised to gain additional understanding about the field data included in the PSDb-2014 and the associated limitations.

\section{Alabama}

Atkins and Hedgecock (1996) published 24 measurements of pier scour at 15 bridge sites in Alabama (table 7). The scour data and associated hydraulic properties were collected by using a sounding weight or fathometer and standard streamflow-gaging procedures (Rantz and others, 1982) during flow events with recurrence intervals ${ }^{1}$ ranging from less than 2 to 10 years. All of the measurements were included in the PSDb-2014. Additional information about the Alabama data can be found in Atkins and Hedgecock (1996) and accessed online (table 4).

\section{Alaska}

Norman (1975) published 38 measurements of pier scour at seven bridge sites in Alaska (table 7). The scour data and associated hydraulic properties were collected by using a fathometer and standard streamflow-gaging procedures (Rantz and others, 1982) during flow events with recurrence intervals ranging from approximately 2 to 100 years. All 38 measurements were included in the PSDb-2014. Froehlich (1988) and the NBSD included 36 common measurements published in Norman (1975). Additional information about the Alaska data can be found in Norman (1975) and the NBSD (U.S. Geological Survey, 2001) and accessed online (table 4).

\footnotetext{
${ }^{1}$ It is currently (2014) recommended that flood-frequency estimates for a given streamflow be reported as the annual exceedance probability rather than recurrence interval. However, "recurrence interval" was the terminology used in all of the data sources cited in this report, and therefore, was used in the report. Definitions for annual exceedance probability and recurrence interval can be found in Feaster and others (2009).
} 
Table 7. Range of selected variables associated with the field data compiled in the PSDb-2014, grouped by State or Country [mi², square miles; ft, foot; $\mathrm{ft} / \mathrm{s}$, foot per second; ft/ft, foot per foot; mm, millimeter; -, missing data]

\begin{tabular}{|c|c|c|c|c|c|c|c|c|c|c|}
\hline $\begin{array}{l}\text { Range } \\
\text { value }\end{array}$ & $\begin{array}{c}\text { Drainage } \\
\text { area } \\
- \\
\mathrm{mi}^{2}\end{array}$ & $\begin{array}{c}\text { Stream } \\
\text { slope } \\
\overline{\mathrm{ft} / \mathrm{ft}}\end{array}$ & $\begin{array}{l}\text { Pier width } \\
\text { normal to } \\
\text { flow } \\
- \\
b_{n} \\
(f t)\end{array}$ & $\begin{array}{c}\text { Approach } \\
\text { flow } \\
\text { velocity } \\
- \\
V_{o} \\
(\mathrm{ft} / \mathrm{s})\end{array}$ & $\begin{array}{c}\text { Approach } \\
\text { flow } \\
\text { depth } \\
- \\
y_{o} \\
\text { (ft) }\end{array}$ & $\begin{array}{c}\text { Median } \\
\text { grain } \\
\text { size } \\
- \\
D 50 \\
(\mathrm{~mm})\end{array}$ & $\begin{array}{l}\text { Measured } \\
\text { pier-scour } \\
\text { depth } \\
- \\
y_{s} \\
(\mathrm{ft})\end{array}$ & $\begin{array}{c}\text { Relative } \\
\text { scour } \\
\text { depth } \\
-y_{s} / b_{n}\end{array}$ & $\begin{array}{c}\text { Relative } \\
\text { flow } \\
\text { depth } \\
-\bar{y}_{o} / b_{n}\end{array}$ & $\begin{array}{c}\text { Relative } \\
\text { sediment } \\
\text { coarseness } \\
- \\
b_{n} / D 50\end{array}$ \\
\hline \multicolumn{11}{|c|}{ Alabama (24 measurements) } \\
\hline Minimum & 112 & - & 1.3 & 1.5 & 5.1 & 0.33 & 0.3 & 0.1 & 0.6 & 89 \\
\hline Median & 246 & - & 2.5 & 3.4 & 12.2 & 2.94 & 1.1 & 0.5 & 4.7 & 418 \\
\hline Maximum & 1,480 & - & 15.4 & 6.8 & 28.6 & 8.60 & 5.8 & 1.0 & 12.3 & 9,580 \\
\hline \multicolumn{11}{|c|}{ Alaska (38 measurements) } \\
\hline Minimum & 150 & 0.0002 & 3.2 & 0.5 & 1.5 & 0.58 & 1.0 & 0.1 & 0.1 & 22 \\
\hline Median & 11,500 & 0.0010 & 5.0 & 5.7 & 10.0 & 3.40 & 2.5 & 0.4 & 1.4 & 758 \\
\hline Maximum & 25,600 & 0.0021 & 30.7 & 12.0 & 22.0 & 90.0 & 8.0 & 1.2 & 4.3 & 2,628 \\
\hline \multicolumn{11}{|c|}{ Arkansas (21 measurements) } \\
\hline Minimum & 121 & - & 1.4 & 1.7 & 7.8 & 0.11 & 2.3 & 0.2 & 0.4 & 44 \\
\hline Median & 1,123 & - & 4.5 & 4.3 & 23.8 & 0.32 & 4.9 & 1.0 & 4.8 & 3,878 \\
\hline Maximum & 52,675 & - & 21.2 & 12.8 & 44.2 & 21.0 & 14.6 & 4.2 & 10.3 & 32,751 \\
\hline \multicolumn{11}{|c|}{ California (10 measurements) } \\
\hline Minimum & - & - & 2.0 & 6.4 & 6.4 & 228.6 & 5.0 & 0.7 & 0.8 & 16 \\
\hline Median & - & - & 4.0 & 9.8 & 7.2 & 228.6 & 9.5 & 1.9 & 1.6 & 24 \\
\hline Maximum & - & - & 21.0 & 18.0 & 28.5 & 228.6 & 15.0 & 5.0 & 4.0 & 28 \\
\hline \multicolumn{11}{|c|}{ Canada (65 measurements) } \\
\hline Minimum & - & 0.0003 & 3.9 & 3.0 & 7.2 & 0.30 & 0.9 & 0.1 & 0.6 & 22 \\
\hline Median & - & 0.0010 & 6.9 & 6.6 & 22.6 & 40.0 & 5.6 & 0.8 & 3.2 & 53 \\
\hline Maximum & - & 0.0030 & 37.4 & 15.1 & 42.0 & 80.0 & 31.0 & 1.7 & 6.4 & 8,941 \\
\hline \multicolumn{11}{|c|}{ China (234 measurements) } \\
\hline Minimum & - & - & 3.3 & 1.1 & 0.4 & 0.2 & 0.3 & 0.0 & 0.0 & 31 \\
\hline Median & - & - & 8.2 & 4.7 & 5.0 & 6.0 & 4.0 & 0.5 & 0.6 & 391 \\
\hline Maximum & - & - & 29.7 & 15.4 & 38.1 & 70.0 & 17.7 & 1.5 & 2.7 & 45,263 \\
\hline \multicolumn{11}{|c|}{ Colorado (66 measurements) } \\
\hline Minimum & 1,590 & 0.0005 & 1.8 & 1.9 & 0.5 & 0.64 & 0.0 & 0.0 & 0.0 & 219 \\
\hline Median & 12,120 & 0.0013 & 7.1 & 3.6 & 3.3 & 0.94 & 1.5 & 0.2 & 0.5 & 2,312 \\
\hline Maximum & 12,120 & 0.0013 & 55.3 & 5.8 & 10.5 & 29.8 & 4.3 & 1.3 & 1.9 & 5,057 \\
\hline \multicolumn{11}{|c|}{ Delaware (34 measurements) } \\
\hline Minimum & - & - & 1.3 & 0.0 & 0.1 & 0.18 & 0.2 & 0.1 & 0.0 & 953 \\
\hline Median & - & - & 2.5 & 1.1 & 12.5 & 0.18 & 0.9 & 0.5 & 7.2 & 4,233 \\
\hline Maximum & - & - & 2.5 & 2.2 & 26.2 & 0.40 & 5.2 & 2.1 & 13.8 & 4,233 \\
\hline \multicolumn{11}{|c|}{ Georgia (8 measurements) } \\
\hline Minimum & 14,000 & - & 4.0 & 1.7 & 18.1 & 1.0 & 3.9 & 0.7 & 3.9 & 1,219 \\
\hline Median & 14,000 & - & 4.0 & 2.0 & 22.0 & 1.0 & 5.0 & 1.1 & 4.6 & 1,219 \\
\hline Maximum & 14,000 & - & 6.0 & 2.3 & 26.4 & 1.0 & 7.0 & 1.8 & 5.8 & 1,829 \\
\hline \multicolumn{11}{|c|}{ Illinois (3 measurements) } \\
\hline Minimum & 708,600 & 0.0003 & 16.1 & 6.0 & 54.8 & 0.6 & 20.4 & 1.2 & 3.0 & 8,188 \\
\hline Median & 708,600 & 0.0003 & 18.0 & 6.6 & 73.4 & 0.6 & 21.4 & 1.2 & 3.7 & 9,151 \\
\hline Maximum & 708,600 & 0.0003 & 20.0 & 8.0 & 73.9 & 0.6 & 23.3 & 1.3 & 4.6 & 10,166 \\
\hline
\end{tabular}


Table 7. Range of selected variables associated with the field data compiled in the PSDb-2014, grouped by State or Country.-Continued [mi², square miles; $\mathrm{ft}$, foot; $\mathrm{ft} / \mathrm{s}$, foot per second; $\mathrm{ft} / \mathrm{ft}$, foot per foot; mm, millimeter; -, missing data]

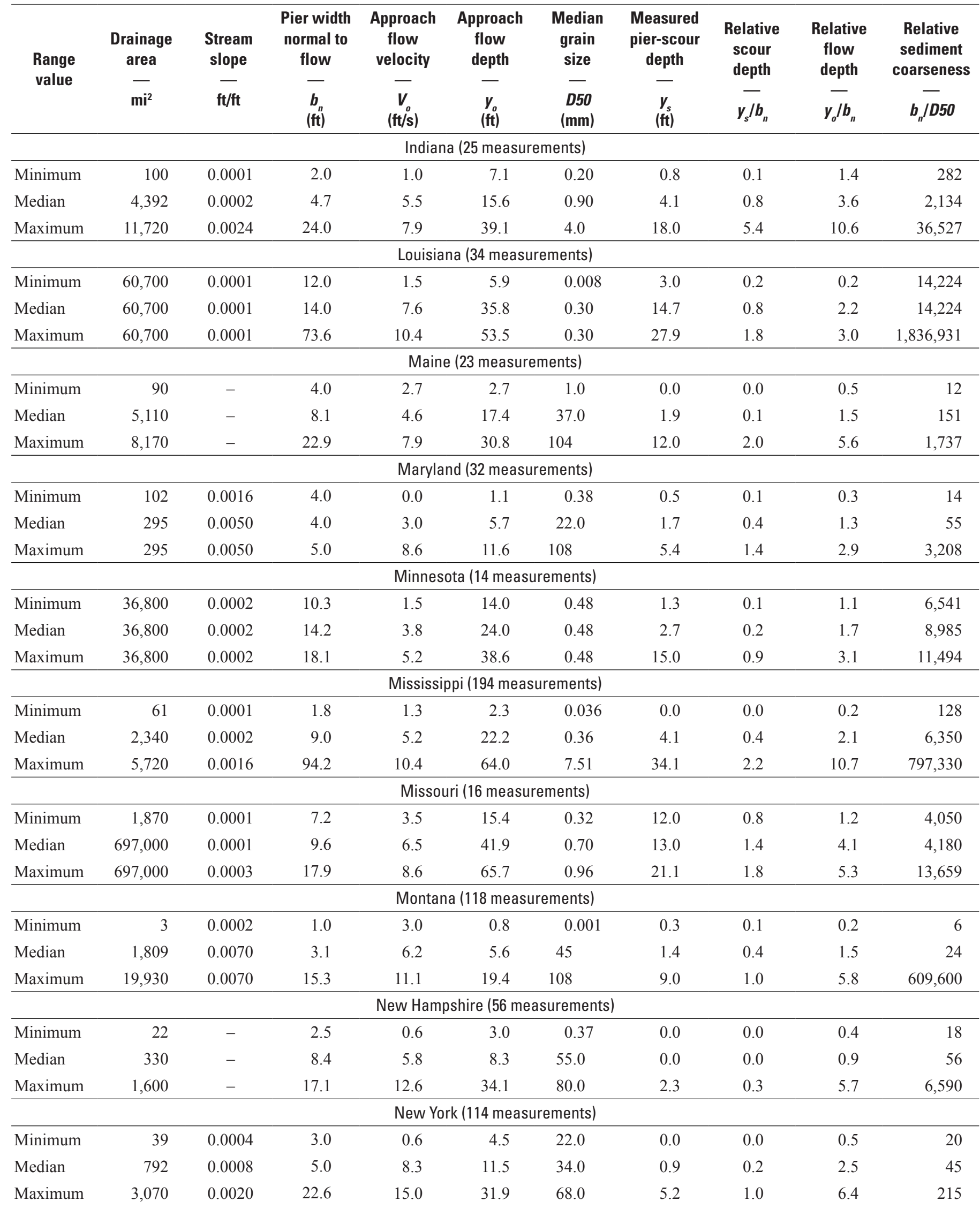




\section{A Pier-Scour Database: 2,427 Field and Laboratory Measurements of Pier Scour}

Table 7. Range of selected variables associated with the field data compiled in the PSDb-2014, grouped by State or Country.-Continued [mi², square miles; $\mathrm{ft}$, foot; $\mathrm{ft} / \mathrm{s}$, foot per second; $\mathrm{ft} / \mathrm{ft}$, foot per foot; $\mathrm{mm}$, millimeter; -, missing data

\begin{tabular}{|c|c|c|c|c|c|c|c|c|c|c|}
\hline $\begin{array}{l}\text { Range } \\
\text { value }\end{array}$ & $\begin{array}{c}\text { Drainage } \\
\text { area } \\
- \\
\mathrm{mi}^{2}\end{array}$ & $\begin{array}{c}\text { Stream } \\
\text { slope } \\
\overline{\mathrm{ft} / \mathrm{ft}}\end{array}$ & $\begin{array}{l}\text { Pier width } \\
\text { normal to } \\
\text { flow } \\
- \\
b_{n} \\
(\mathrm{ft})\end{array}$ & $\begin{array}{c}\text { Approach } \\
\text { flow } \\
\text { velocity } \\
- \\
V_{o} \\
(\mathrm{ft} / \mathrm{s})\end{array}$ & $\begin{array}{c}\text { Approach } \\
\text { flow } \\
\text { depth } \\
- \\
y_{o} \\
\text { (ft) }\end{array}$ & $\begin{array}{l}\text { Median } \\
\text { grain } \\
\text { size } \\
- \\
D 50 \\
(\mathrm{~mm})\end{array}$ & $\begin{array}{l}\text { Measured } \\
\text { pier-scour } \\
\text { depth } \\
- \\
y_{s} \\
(\mathrm{ft})\end{array}$ & $\begin{array}{c}\text { Relative } \\
\text { scour } \\
\text { depth } \\
-y_{s} / b_{n}\end{array}$ & $\begin{array}{c}\text { Relative } \\
\text { flow } \\
\text { depth } \\
-\bar{y}_{o} / b_{n}\end{array}$ & $\begin{array}{c}\text { Relative } \\
\text { sediment } \\
\text { coarseness } \\
-\overline{b_{n} / D 50}\end{array}$ \\
\hline \multicolumn{11}{|c|}{ New Zealand (12 measurements) } \\
\hline Minimum & - & - & 5.0 & 3.1 & 2.0 & 0.78 & 1.3 & 0.3 & 0.4 & 76 \\
\hline Median & - & - & 5.0 & 8.0 & 4.3 & 20.0 & 2.1 & 0.4 & 0.9 & 76 \\
\hline Maximum & - & - & 12.8 & 8.8 & 11.3 & 20.0 & 9.0 & 0.9 & 2.0 & 4,998 \\
\hline \multicolumn{11}{|c|}{ Nigeria (1 measurement) } \\
\hline Minimum & - & - & 33.1 & 2.1 & 29.5 & 0.67 & 25.6 & 0.8 & 0.9 & 15,058 \\
\hline Median & - & - & 33.1 & 2.1 & 29.5 & 0.67 & 25.6 & 0.8 & 0.9 & 15,058 \\
\hline Maximum & - & - & 33.1 & 2.1 & 29.5 & 0.67 & 25.6 & 0.8 & 0.9 & 15,058 \\
\hline \multicolumn{11}{|c|}{ Ohio (87 measurements) } \\
\hline Minimum & 84 & 0.0001 & 1.0 & 0.5 & 3.0 & 0.01 & 0.4 & 0.0 & 0.1 & 13 \\
\hline Median & 675 & 0.0005 & 8.7 & 3.2 & 8.4 & 6.80 & 1.7 & 0.2 & 1.3 & 646 \\
\hline Maximum & 3,849 & 0.0036 & 53.4 & 9.3 & 19.8 & 60.0 & 23.1 & 1.1 & 5.9 & $1,630,000$ \\
\hline \multicolumn{11}{|c|}{ Oklahoma (17 measurements) } \\
\hline Minimum & - & - & 2.5 & - & - & - & 0.6 & 0.2 & - & - \\
\hline Median & - & - & 4.3 & - & - & - & 8.0 & 0.9 & - & - \\
\hline Maximum & - & - & 20.0 & - & - & - & 18.0 & 4.0 & - & - \\
\hline \multicolumn{11}{|c|}{ Russia (83 measurements) } \\
\hline Minimum & - & - & 0.7 & 1.1 & 1.0 & 0.20 & 0.6 & 0.2 & 0.3 & 533 \\
\hline Median & - & - & 10.0 & 3.6 & 10.2 & 0.30 & 8.5 & 1.0 & 1.6 & 15,037 \\
\hline Maximum & - & - & 33.5 & 8.9 & 56.1 & 1.80 & 18.9 & 1.8 & 7.3 & 34,036 \\
\hline \multicolumn{11}{|c|}{ South Carolina (335 measurements) } \\
\hline Minimum & 11 & 0.0001 & 0.8 & 0.4 & 1.3 & 0.004 & 0.0 & 0.0 & 0.4 & 179 \\
\hline Median & 307 & 0.0006 & 1.5 & 3.3 & 9.9 & 0.30 & 1.5 & 0.8 & 4.8 & 2,067 \\
\hline Maximum & 12,990 & 0.0029 & 19.6 & 12.1 & 50.8 & 1.70 & 16.9 & 3.7 & 26.3 & 178,528 \\
\hline \multicolumn{11}{|c|}{ Virginia (186 measurements) } \\
\hline Minimum & 64 & 0.0001 & 2.0 & 0.0 & 0.0 & 0.28 & 0.0 & 0.0 & 0.0 & 8 \\
\hline Median & 1,081 & 0.0002 & 2.9 & 1.9 & 11.6 & 0.74 & 1.5 & 0.6 & 4.2 & 1,195 \\
\hline Maximum & 2,730 & 0.0029 & 3.2 & 8.5 & 32.5 & 72.0 & 5.1 & 1.7 & 10.8 & 3,483 \\
\hline \multicolumn{11}{|c|}{ Washington (6 measurements) } \\
\hline Minimum & 82 & 0.0066 & 1.5 & 4.0 & 8.1 & 15.9 & 1.7 & 0.2 & 0.6 & 115 \\
\hline Median & 178 & 0.0200 & 4.5 & 10.0 & 12.7 & 15.9 & 3.1 & 0.9 & 3.9 & 115 \\
\hline Maximum & 517 & 0.0200 & 24.3 & 11.0 & 18.1 & 15.9 & 8.0 & 1.7 & 6.8 & 115 \\
\hline \multicolumn{11}{|c|}{ Yugoslavia (2 measurements) } \\
\hline Minimum & - & - & 14.8 & 6.0 & 57.1 & 0.25 & 9.8 & 0.7 & 3.9 & 18,000 \\
\hline Median & - & - & 14.8 & 6.8 & 59.4 & 0.25 & 12.0 & 0.8 & 4.0 & 18,000 \\
\hline Maximum & - & - & 14.8 & 7.5 & 61.7 & 0.25 & 14.1 & 1.0 & 4.2 & 18,000 \\
\hline
\end{tabular}




\section{Arkansas}

Southard (1992) published 22 measurements of pier scour at 12 bridge sites in Arkansas (table 7). The scour data and associated hydraulic properties were collected by using soundings and standard streamflow-gaging procedures (Rantz and others, 1982) during flow events with recurrence intervals ranging from approximately 3 to 100 years. All but 1 of the 22 measurements were included in the PSDb-2014. Seven of the measurements were included in the NBSD. The one excluded measurement (May 13, 1968, Saline River at U.S. Highway 70) was likely influenced by abutment scour. Additional information about the Arkansas data can be found in Southard (1992) and the NBSD (U.S. Geological Survey, 2001), and accessed online (table 4).

\section{California}

Shen (1975) reviewed selected bridge-maintenance records from the California Department of Transportation and identified 16 measurements of pier scour at 12 bridge sites in California (table 7). The data were collected by various methods including post-flood soundings near the piers (1 site), post-flood analyses of soil borings ( 9 sites), and unknown methods ( 2 sites). The analysis of post-flood soil borings is a useful method for assessing scour depths. However, the interpretive nature of this method introduces additional uncertainty into the scour measurement. Hydraulic properties were approximated at 6 of the 12 sites by using limited historical information regarding the floods thought to have created the measured scour. These approximated hydraulic properties associated with these pier-scour data typically consisted of the average flow depth and velocity at the bridge. Six measurements without hydraulic estimates were excluded from the database; therefore, only 10 measurements were included in the PSDb-2014. Based on photographs, it appears that most of the piers associated with the 10 measurements have footings which could potentially influence scour. Additionally, seven of these measurements are associated with moderate to substantial debris accumulations. While the California data are useful for gaining insights into pier-scour relations, the uncertainty associated with the scour-measurement method, the approximate hydraulic properties, pier footings, and debris accumulation should be considered when using these data in any scour analysis. Additional information about the California data can be found in Shen (1975) and accessed online (table 4).

\section{Canada}

The PSDb-2014 includes 65 field measurements from Canada, including 61 measurements collected in Alberta by Alberta Transportation (Williamson, 1993; C. Watt, Alberta Transportation, written commun., November 2012), 3 measurements published in Neill $(1964,1965)$, and 1 measurement published in Froehlich (1988) (table 7). The field data from Alberta Transportation represent selected data taken from the agency's pier-scour survey program (Williamson, 1993). This program includes collection of periodic measurements of pierscour at selected bridges throughout the province of Alberta and has been ongoing since the late 1950s. Scour measurements were obtained by various sounding techniques with most measurements representing post-flood data that could possibly include limited amounts of infill. The hydraulic properties associated with the measurements are estimates of the peak-flow conditions at the time of the flood with recurrence intervals for 42 measurements ranging from less than 5 to 100 years. Additional information about the Alberta Transportation pier-scour survey program can be found in Williamson (1993) and Chapter 9 of the agency's Bridge Inspection and Maintenance System-Level 2 Inspection Manual (Alberta Transportation, 2007). All of the Alberta Transportation measurements from Williamson (1993) and Watt (written commun., November 2012) were included in the PSDb-2014.

Neill (1964) conducted a review of selected laboratory investigations of pier scour and made a limited comparison with field measurements from eight bridge sites in Canada. Some of the sites had complex features such as rip rap, exposed footings, and contraction scour in conjunction with pier scour, and these measurements were excluded; however, three of the measurements were included in the PSDb-2014. These measurements have limited documentation making it difficult to fully assess the quality of the data, and this should be considered when using these data in any scour analysis. Froehlich (1988) included one measurement from Canada that was originally published in Neill (1965), and this measurement was included in the PSDb-2014.

\section{China and Russia}

Sheppard and others (2011) compiled 943 field measurements of pier scour from four sources including Zhuravlyov (1978), Froehlich (1988), Gao and others (1993), and Mueller and Wagner (2005). The compiled data included 252 measurements from China (Gao and others, 1993) and 187 measurements from Russia (Zhuravlyov, 1978). Sheppard and others (2011) noted that "there is little information regarding the measurement and data reduction techniques (e.g., how local scour was distinguished from the other forms of scour, how the measurements were made, etc.)" for the data making it difficult to assess the quality of the data in comparison to the more thoroughly documented data in Froehlich (1988) and Mueller and Wagner (2005). Sheppard and others (2011) screened the field data from China and Russia by comparing it with the more thoroughly documented data and removed selected data that seemed inconsistent with the Froehlich (1988) and Mueller and Wagner (2005) data. The screened measurements, as published in Sheppard and others (2011), were included in the PSDb-2014 with 234 measurements from China and 83 measurements from Russia (table 7). Additional information about the data from China and Russia can be found in Gao and others (1993), Zhuravlyov (1978), and Sheppard and others (2011), some of which can be accessed online (table 4). 


\section{Colorado}

Jarrett and Boyle (1986) conducted a pilot study to develop and test guidelines for collecting streambed-scour data at bridges during high flows. Jarrett and Boyle (1986) collected pier-scour and hydraulic data by using a sounding weight and standard streamflow-gaging procedures (Rantz and others, 1982) at the upstream and downstream faces of four bridge sites that included 21 piers in Colorado. The data were collected during two events associated with record or nearrecord snow packs in the basin headwaters and during one lower flow condition. Jarrett and Boyle (1986) only published the maximum pier-scour depth at each bridge associated with the two high-flow events (8 measurements). Froehlich (1988) included 15 measurements in his investigation, using the data from Jarrett and Boyle (1986) and obtaining additional data by written communication. The NBSD includes 63 pier-scour measurements taken from the original field data collected for the Jarrett and Boyle (1986) investigation. Twelve of the measurements in the NBSD also were included in Froehlich (1988), but the NBSD had slightly different values based on the reinterpretation of the data. In such cases, preference was given to the NBSD data with any differing values published in Froehlich (1988) noted in the PSDb-2014 spreadsheet. All 66 measurements (table 7) were included in the PSDb-2014. Additional information about the Colorado data can be found in Jarrett and Boyle (1986) and the NBSD (U.S. Geological Survey, 2001) and accessed online (table 4).

\section{Delaware}

Hayes (1996) collected pier-scour measurements at 15 bridge sites in the States of Delaware, Maryland, and Virginia. The scour data and associated hydraulic properties were collected by using a sounding weight or fathometer and standard streamflow-gaging procedures (Rantz and others, 1982). Thirty-four measurements collected at two bridge sites in Delaware (table 7) were included in the PSDb-2014, with all of these measurements in common with the NBSD. Hayes (1996) published the total flow depth at the pier, which represents the total flow depth from the water surface to the bottom of the scour hole, and this total flow depth was used in the NBSD to represent the approach flow depth. In the PSDb2014, the approach flow depth for the Hayes (1996) data was determined by subtracting the pier-scour depth from the total flow depth. Additional information about the Delaware data can be found in Hayes (1996) and the NBSD (U.S. Geological Survey, 2001) and accessed online (table 4).

\section{Georgia}

The NBSD included eight measurements of pier scour collected at the Interstate 95 crossing of the Altamaha River located in southeastern Georgia (table 7). The scour data and associated hydraulic properties were collected by using a fathometer and standard streamflow-gaging procedures (Rantz and others, 1982). This site is tidally affected, but the flow does not normally reverse direction over the tide cycle. All of the measurements were included in the PSDb-2014. Additional information about the Georgia data can be found in the NBSD (U.S. Geological Survey, 2001) and accessed online (table 4).

\section{Illinois}

The NBSD included three measurements of pier scour collected in Illinois during the 1993 flood in the upper Mississippi River Basin. The scour data and associated hydraulic properties, originally published in Mueller and others (1995), were collected by using a fathometer and standard streamflowgaging procedures (Rantz and others, 1982), and all three measurements were included in the PSDb-2014. Additional information about the Illinois data can be found in the NBSD (U.S. Geological Survey, 2001) and accessed online (table 4).

\section{Indiana}

The PSDb-2014 includes 25 measurements from Indiana, including 15 measurements of pier scour collected by Mueller and others (1994) at 9 bridges and 10 measurements published in the NBSD (table 7). The data collected by Mueller and others (1994) are historical scour measurements (similar to post-flood measurements) that, at the time of the field measurement, were assumed to represent the maximum pier-scour depth at the bridge pier since the bridge was constructed. (A more detailed description of historical scour measurements is provided later in the report under the section "South Carolina.") Ground-penetrating radar (GPR) was used to measure the maximum historical pier-scour depth at the pier, and the hydraulic properties associated with these pier-scour data were determined from a one-dimensional flow model based on the historical peak flow at the bridge. GPR has been used successfully to locate and estimate scour depths in the field (Placzek and Haeni, 1995; Webb and others, 2000; Benedict and Caldwell, 2009). The interpretive nature of this method introduces additional uncertainty into the scour measurement (Benedict and Caldwell, 2009), and this should be considered when analyzing the data collected by GPR. The NBSD data were collected by using soundings and standard streamflowgaging procedures (Rantz and others, 1982). Additional information about the Indiana data can be found in Mueller and others (1994) and the NBSD (U.S. Geological Survey, 2001) and accessed online (table 4).

\section{Louisiana}

The PSDb-2014 contains 34 measurements from Louisiana, including 20 measurements associated with 1 bridge site from the NBSD and 14 from Chang (1980) as cited in Froehlich (1988) (table 7). The NBSD pier-scour data and associated hydraulic properties were collected by using a fathometer and standard streamflow-gaging procedures (Rantz and others, 1982). The Chang (1980) measurements were taken from Froehlich (1988). Additional information about the Louisiana data can be found in the NBSD (U.S. Geological Survey, 2001) and Froehlich (1988) and accessed online (table 4). 
Maine

Hodgkins and Lombard (2002) published 23 measurements of pier scour at 8 bridge sites in Maine (table 7). The scour data and associated hydraulic properties were collected by using soundings and standard streamflow-gaging procedures (Rantz and others, 1982) during flow events with recurrence intervals ranging from less than 2 to 25 years. The piers associated with these measurements have footings which could potentially influence scour. Information about the footings is in Hodgkins and Lombard (2002). All of the measurements were included in the PSDb-2014. Additional information about the Maine data can be found in Hodgkins and Lombard (2002) and accessed online (table 4).

\section{Maryland}

Hayes (1996) collected pier-scour measurements at 15 bridge sites in the States of Delaware, Maryland, and Virginia. The scour data and associated hydraulic properties were collected by using a sounding weight or fathometer and standard streamflow-gaging procedures (Rantz and others, 1982). Thirty-two measurements collected at 3 bridge sites in Maryland (table 7) were included in the PSDb-2014, with 20 of these measurements also in the NBSD. Hayes (1996) published the total flow depth at the pier, which represents the total flow depth from the water surface to the bottom of the scour hole, and this total flow depth was used in the NBSD to represent the approach flow depth. In the PSDb-2014, the approach flow depth for the Hayes (1996) data was determined by subtracting the pier-scour depth from the total flow depth. Additional information about the Maryland data can be found in Hayes (1996) and the NBSD (U.S. Geological Survey, 2001) and accessed online (table 4).

\section{Minnesota}

The PSDb-2014 includes 14 field measurements from Minnesota published in the NBSD (table 7). The documentation in the NBSD does not state the method of data collection. Additional information about the Minnesota data can be found in the NBSD (U.S. Geological Survey, 2001) and accessed online (table 4).

\section{Mississippi}

The PSDb-2014 includes 194 measurements from Mississippi, including 190 measurements from Wilson (1995), with 45 of those measurements also in the NBSD, 2 additional measurements from the NBSD, and 2 from Chang (1980) as cited in Froehlich (1988) (table 7). The scour data and associated hydraulic properties for the data in Wilson (1995) and the NBSD were collected by using a sounding weight or fathometer and standard streamflow-gaging procedures (Rantz and others, 1982) with recurrence intervals ranging from less than 2 to about 500 years. Additional information about the Mississippi data can be found in Wilson (1995), Froehlich (1988), and the NBSD (U.S. Geological Survey, 2001), some of which can be accessed online (table 4).

\section{Missouri}

The PSDb-2014 includes 16 field measurements from Missouri that were included in the NBSD (table 7). Eleven of these measurements were originally published in Mueller and others (1995) and were noted to have recurrence intervals greater than 100 years. The scour data and associated hydraulic properties were collected by using a sounding weight or fathometer and standard streamflow-gaging procedures (Rantz and others, 1982). Additional information about the Missouri data can be found in Mueller and others (1995) and the NBSD (U.S. Geological Survey, 2001) and accessed online (table 4).

\section{Montana}

The PSDb-2014 includes 118 measurements from Montana, with 103 measurements from Holnbeck (2011) and 15 from the NBSD (table 7). [Note: The NBSD includes 41 measurements from Montana; however, 26 were excluded based on guidance from S.R. Holnbeck of the USGS WyomingMontana Water Science Center (written commun., January 2014), because of limitations associated with the data.] The scour data and associated hydraulic properties were collected primarily with a sounding weight and standard streamflowgaging procedures (Rantz and others, 1982) during flow events with recurrence intervals of approximately 2 years for the Holnbeck (2011) data and from 2 to 100 years for the NBSD data. Hydraulic characteristics at selected sites in the NBSD data were determined from hydraulic models. All 118 measurements were included in the PSDb-2014. The Montana data from Holnbeck (2011) represent the single largest coarse-bed pier-scour database collected to date by the USGS, and these high-quality data need no qualifications. In contrast, the Montana data associated with the NBSD may reflect remnant scour holes (S.R. Holnbeck, USGS Wyoming-Montana Water Science Center, written commun., January 2014) which should be taken into consideration when using these data in any analysis. Additional information about the Montana data can be found in Holnbeck (2011) and the NBSD (U.S. Geological Survey, 2001) and accessed online (table 4).

\section{New Hampshire}

Boehmler and Olimpio (2000) published 56 measurements of pier scour at 20 bridge sites in New Hampshire (table 7). The scour data were collected by various methods including GPR, fixed instruments, and soundings. The hydraulic properties associated with these pier-scour data were determined from standard streamflow-gaging procedures (Rantz and others, 1982) or from hydraulic models, with recurrence intervals ranging from less than 2 to approximately 100 years. The interpretive nature of GPR introduces additional uncertainty into the scour measurement (Benedict and Caldwell, 2009), and this should be considered when analyzing the data collected by GPR. Some of the data reflect measurements at the same pier for the same flow event using different measurement methods. Additionally, some of the data reflect the change in 
scour from a past flow event rather than the maximum scour since bridge construction. These characteristics should be considered when using these data in any scour analysis. All of the measurements were included in the PSDb-2014. Additional information about the New Hampshire data can be found in Boehmler and Olimpio (2000) and accessed online (table 4).

\section{New York}

The PSDb-2014 includes 114 measurements from New York, including 110 measurements received from the New York Water Science Center (Butch, 1991; G. Butch, written commun., July 2008), with 25 of these measurements also in the NBSD and an additional 4 measurements from the NBSD (table 7). The scour data were collected by soundings or from cross-section data at the bridge site. The hydraulic properties for the data were mostly obtained from a hydraulic model calibrated to the peak flow associated with the scour measurement, with some hydraulic properties obtained from flow measurements (G. Butch, written commun., August 2013). The NBSD often assumed that a past flow event of larger magnitude than that at the time of the scour measurement created the observed scour, and hydraulic properties associated with the past event were recorded for the scour measurement. The recurrence intervals associated with the pier-scour data ranged from less than 2 to greater than 100 years. All 114 measurements were included in PSDb-2014. Additional information about the New York data can be found in Butch (1991), Welch and Butch, (2001), and the NBSD (U.S. Geological Survey, 2001), and some of this information can be accessed online (table 4).

\section{Ohio}

Jackson (1997) published 85 measurements of pier scour at 20 bridge sites in Ohio (table 7). All of these data are also in the NBSD. The scour data and associated hydraulic properties were collected by using a sounding weight or fathometer and standard streamflow-gaging procedures (Rantz and others, 1982), with recurrence intervals ranging from less than 2 to greater than 50 years. All 85 measurements were included in the PSDb-2014. An additional two measurements from Mueller and others (1994) were included in the PSDb-2014. These were historical measurements collected with GPR with hydraulic properties estimated with a model. The interpretive nature of GPR introduces additional uncertainty into the scour measurement (Benedict and Caldwell, 2009), and this should be considered when analyzing the data collected by GPR. Additional information about the Ohio data can be found in Mueller and others (1994), Jackson (1997), and the NBSD (U.S. Geological Survey, 2001) and accessed online (table 4).

\section{Oklahoma}

Tyagi (1987) published 17 measurements of pier-scour depth from bridge sites in Oklahoma (table 7). The data are post-flood measurements taken after a large flood in October
1986 with a recurrence interval between 50 and 100 years. The pier widths associated with the measurements were determined from scaled drawings of the scour holes and piers included in the report. Hydraulic properties associated with these pier-scour data were not published. All 17 measurements were included in the PSDb-2014. While these measurements have limited supporting data, the pier width and scour depth data can be used to assess upper bounds of relative scour and therefore, were included in the PSDb-2014. The Oklahoma data can be useful for gaining insights into pier-scour relations, but the limited documentation makes it difficult to fully assess the quality of the data. This should be considered when using these data in any scour analysis. Additional information about the Oklahoma data can be found in Tyagi (1987; table 4).

\section{South Carolina}

Benedict and Caldwell $(2006,2009)$ published 335 measurements of pier scour in South Carolina that included 189 measurements of clear-water scour on the overbanks of 112 bridges and 146 measurements of live-bed scour in the main channel at 61 bridges (Benedict and Caldwell, 2006; table 7). The data are historical scour measurements (similar to post-flood measurements) that, at the time of the field measurement, were assumed to represent the maximum pier-scour depth at the bridge pier since the bridge was constructed.

In the case of clear-water scour measurements on the bridge overbank, the minimal infill of the scour holes allowed for the direct measurement of the pier-scour depth using standard surveying techniques. In the case of live-bed scour measurements in the main channel, where infill sediments partially or totally refill the scour holes, GPR was used to measure the maximum historical pier-scour depth at the pier. As noted previously, GPR is a useful tool for measuring scour. However, the interpretive nature of this method introduces additional uncertainty into the scour measurement. Benedict and Caldwell (2009) noted that the average trend line (pier width versus scour depth) through the South Carolina live-bed pier-scour data was approximately 1 to $2 \mathrm{ft}$ above the trend line for selected field data from the NBSD, indicating that the South Carolina live-bed pier-scour measurements are slight overestimates of the actual scour depths. The uncertainty and overestimate of scour depths associated with the South Carolina live-bed pier-scour data should be considered when using these data.

The hydraulic properties for the clear-water and live-bed pier-scour data were estimated with a one-dimensional flow model using the maximum historic flow since the bridge was constructed as determined from limited historical flow records. When historical flow records were not available for a bridge of interest, the 100-year flow was used as a common index flow. Use of the 100-year flow as a common index flow was based on a review of limited historic flood data that indicated bridge sites in the investigation had likely experienced historical flows equaling or exceeding 70 percent of the 100-year 
flow. The hydraulic properties based on the 100-year index flow are likely high estimates of the hydraulic conditions that created the scour, and this should be kept in mind when analyzing these data. For the clear-water pier-scour data, 88 of the 189 scour measurements have hydraulic data based on the maximum historical flow since the bridge was constructed, and the remaining data use the 100 -year index flow. For the live-bed pier-scour data, 122 of the 146 scour measurements have hydraulic data based on the maximum historical flow since the bridge was constructed, and the remaining data use the 100-year index flow.

Benedict and Caldwell $(2006,2009)$ did not report the recurrence interval associated with the maximum historical flow, but rather the ratio of the maximum historical flow with respect to the 100-year flow. By using this ratio, approximate recurrence intervals were estimated for the maximum historical flows and were included in the PSDb-2014. These flood frequency values were not rigorously calculated and should be considered approximate only. The recurrence interval for measurements using the 100-year index flow was identified as the "100 (index)." All of the clear-water and live-bed pier-scour measurements were included in the PSDb-2014. Additional information about the South Carolina data can be found in Benedict and Caldwell (2006, 2009).

\section{Virginia}

Hayes (1996) collected pier-scour measurements at 15 bridge sites in the States of Delaware, Maryland, and Virginia. The scour data and associated hydraulic properties were collected by using a sounding weight or fathometer and standard streamflow-gaging procedures (Rantz and others, 1982). One hundred and eighty-six measurements collected at 9 bridge sites in Virginia (table 7) were included in the PSDb-2014, with 81 of these measurements also in the NBSD. Hayes (1996) published the total flow depth at the pier, which represents the total flow depth from the water surface to the bottom of the scour hole, and this total flow depth was used in the NBSD to represent the approach flow depth. In the PSDb2014, the approach flow depth for the Hayes (1996) data was determined by subtracting the pier-scour depth from the total flow depth. Additional information about the Maryland data can be found in Hayes (1996) and the NBSD (U.S. Geological Survey, 2001) and accessed online (table 4).

\section{Washington}

Copp and Johnson (1987) published six measurements of pier scour at six bridge sites in Washington (table 7). The data are similar to historical scour measurements that represent the maximum scour depth since bridge construction at the time of the site visit. The data were collected at low-flow conditions using various surveying techniques. The hydraulic properties associated with these pier-scour measurements, as presented in Copp and Johnson (1987), were estimated from limited flow information and represent average hydraulic properties in the bridge opening. The piers associated with these measurements have footings which could potentially influence scour. Limited information on the footings is provided in Copp and Johnson (1987). The six measurements were included in the PSDb2014. While the Washington data are useful for gaining insights into pier-scour relations, the uncertainty associated with the scour-measurement method, the approximate hydraulic properties, and influence of pier footings, should be considered when using these data in any scour analysis. Additional information about the Washington data can be found in Copp and Johnson (1987) and accessed online (table 4).

\section{Limitations of Field Data}

Investigations of scour in the controlled environment of the laboratory allow for relatively accurate and precise measurements of downscaled parameters used in the analysis of pier scour including sediment grain size, pier width normal to flow, flow depth, flow velocity, and scour depth. In the complex and harsh environment of the field, however, measuring these parameters can be a difficult task that typically cannot be accomplished to the same degree of accuracy and thoroughness as in the controlled environment of a flume study in a laboratory. Field measurements of pier scour, therefore, must be understood to generally have more uncertainty and potential error than that associated with laboratory data. While the uncertainty must be acknowledged, previous investigations have demonstrated that the general patterns of field data are similar to those of laboratory data (Mueller and Wagner, 2005; Benedict and Caldwell, 2006, 2009; Sheppard and others, 2011) and can be used to confirm and extend the findings of laboratory investigations. The uncertainty associated with the field data will typically be displayed by larger scatter within various relations and by outliers that require some investigation to determine the cause of the divergence from the majority of the data. Additionally, measurement quality will vary with the techniques used to collect the field data, and data collected by one technique to quantify a certain parameter may display a slightly different relation from data collected by a different technique intended to quantify the same parameter. Therefore, it is important to understand the limitations of field data, in general, as well as the limitation of selected data based on measurement techniques. To help provide an understanding of data limitations, potential sources of measurement error in the field data are described in this section of the report. This information may be helpful to evaluate the quality of a given measurement and perhaps explain why selected measurements deviate from the majority of the data. A review of the sources of the field data included in the PSDb-2014 is advised to gain additional understanding about the data and its associated limitations (table 4). 


\section{Equilibrium Scour Depth}

The pier-scour field data typically reflect measurements during a short time increment in the scour event, and the history of the scour-depth evolution is unknown. Some of the pierscour measurements may reflect remnant scour holes created by previous flow events of larger magnitude, and the concurrent (or assumed) hydraulic conditions associated with the measured scour may not be the flow conditions that created the scour. This observation may apply more at sites where clear-water scour conditions predominate and where a much larger flood had occurred in the recent past. Scour measurements may not, therefore, reflect equilibrium scour depths for the associated flow conditions, particularly at some sites with conditions similar to those described above.

\section{Measurement Technique}

The pier-scour field data were collected with various measurement techniques, including survey levels, soundings using fathometers or sounding weights, geophysical equipment, and soil borings. The accuracy of a pier-scour measurement varies with the measurement technique. As noted previously, GPR is a useful tool for assessing scour, but the interpretive nature of this method introduces additional uncertainty into the scour measurement. (See the report section "South Carolina" for additional information regarding potential error associated with GPR measurements.) Similarly, the use of soil borings to estimate scour depth requires interpretation, which introduces additional uncertainty in that estimate. While all measurement techniques used in the PSDb2014 yield useful data, measurements associated with standard surveying methods and soundings by fathometers or sounding weights likely provide the most accurate scour measurements. To provide insights into the potential accuracy of a given pier-scour measurement, the measurement technique used to collect the data was noted in the PSDb-2014, if such information was available.

\section{Measurement Type}

The pier-scour measurements were classified into three measurement-type categories: historical, post-flood, and flood measurements. For the historical measurement category, the measured scour is assumed to reflect the maximum scour depth that has occurred at a pier since bridge construction. For clear-water scour sites that have minimal infill, historical scour can typically be measured by survey or soundings. For livebed scour sites where scour holes may have some infill, historical scour is often measured with geophysical techniques, such as GPR (Mueller and others, 1994; Benedict and Caldwell, 2009) in order to evaluate the maximum scour depth.

Post-flood measurements are scour depths measured shortly after a flood by using various measurement techniques. Some scour holes associated with post-flood measurements may have infill, and therefore, the scour that actually occurred may be underestimated. This underestimation is more likely to occur at live-bed scour sites where geophysical techniques were not used to measure the scour depth.

Flood measurements are scour depths measured during high flow, typically with sounding weights or a fathometer. While all three types of pier-scour measurements yield useful data, flood measurements likely provide the most accurate scour measurements because the measurements are directly associated with concurrent flow and scour conditions. The measurement type for a given pier-scour measurement was noted in the PSDb-2014 if such information was available.

\section{Determination of Hydraulic Properties}

The hydraulic properties associated with a given pierscour measurement were generally determined by one of three methods: estimates from limited historical information, one-dimensional flow models based on flows thought to have created the measured scour, or flow measurements concurrent with the scour measurements. Hydraulic properties based on limited historical information reflect approximate values that were determined without the aid of current meter measurements or models and likely have the largest measurement uncertainty. Historical and post-flood scour measurements typically relied on one-dimensional flow models to estimate the hydraulic properties that may have created the scour. In the case of post-flood scour measurements, the historical flows used in these models typically represented conditions for a known flow event occurring just prior to the scour measurement. For historical scour measurements, the historical flows used in these models typically represented the maximum historical flow since bridge construction as determined from historical flow records or an assumed index flow. The accuracy of the historical flows used in the one-dimensional flow models will influence the degree of uncertainty associated with the estimated hydraulic properties derived from those models. Models using an assumed index flow likely have a larger uncertainty associated with the estimate of the hydraulic properties. Flow measurements concurrent with the scour measurements likely provide the most accurate estimates of the hydraulic properties that created the scour; therefore, if a given pier-scour analysis is dependent upon hydraulic properties, it may be advisable to give preference to data associated with flow measurements concurrent with the scour measurement. To provide insights into the potential accuracy of the hydraulic properties associated with a given pier-scour measurement, the method for determining the hydraulic properties was noted in the PSDb-2014 if such information was available.

\section{Sediment Characteristics}

Sediments in the field are non-uniform in grain size and typically have characteristics that vary spatially. Floodplain sediments, in particular, reflect the varying depositional 
environments that created them. Additionally, natural streams often have subsurface strata that can be more or less resistant to scour than the surface sediments. Where there is underlying bedrock of competent nature, pier-scour depths may be limited by the more scour-resistant underlying material. In contrast, coarse-bed alluvial streams having non-uniform sediment characteristics can experience armoring during high flows. Armoring occurs when the upper layer of sediments coarsens as flows remove the finer material; the remaining coarser material may then armor the scour hole, causing the hole to be more resistant to further scour. If the armor layer is mobilized, scour may resume and accelerate if the underlying material is not of sufficient size and gradation. The median grain size, the grain-size distributions, and a simple description of the sediments based on limited samples of surface bed material are provided for certain sites in the PSDb-2014. Such data are useful for defining the bed sediments, but are subject to any limitations in the data.

\section{Pier Width Normal to Flow}

The pier width normal to flow is the width of the pier projected to the approaching flow and is known to influence the depth of pier scour (Ettema and others, 2011; Sheppard and others, 2011). An accurate determination of the pier width normal to flow requires knowledge of the nominal pier width (the width at the frontal pier face measured perpendicular to the flow), the pier length, and the skew angle of the approaching flow to the major axis of the pier, as shown in the following equation:

$$
b_{n}=b \operatorname{cosin} e \theta+L \sin e \theta,
$$

where
$b_{n} \quad$ is the pier width normal to flow, in feet;
$b$ is the nominal pier width, in feet;
$\theta \quad$ is the skew angle of the major axis of the pier with respect to approaching flow, in degrees; and
$L \quad$ is the pier length along the major axis, in feet.

The nominal pier width and pier length can be readily determined for uniform pier geometries; however, at complex and non-uniform pier geometries, which are often associated with larger piers, the determination of these variables can be challenging. The most accurate measurement of the skew angle is obtained during flood conditions and concurrent with the scour measurement. For historical and post-flood scour measurements, the skew angle is typically determined from a review of site characteristics during low-flow conditions and topographic maps and therefore has a larger uncertainty. The challenges of accurately determining the variables in equation 1 introduce some uncertainty in those data, as well as in the estimate of the pier width normal to flow, and this should be taken into consideration when using these variables in any analysis. The data for the nominal pier width, pier length, skew angle, and pier width normal to flow were incorporated into the PSDb-2014 as published in the cited sources with no attempt to verify those values. Some sources did not publish the pier width normal to flow; in such cases, this value was determined by using equation 1 .

\section{Real-Time Scour Evaluation}

Pier-scour data collected by the flood-measurement method (previously defined) should represent scour resulting from the hydraulic conditions at the time of the field measurement (real-time scour). Some flood measurements of pier scour may reflect remnant scour created by a past flow event larger than the measured flow. Of particular concern are cases where the flow conditions measured concurrently with the pier scour are insufficient to initiate scour at a pier and therefore, no real-time scour was occurring at the time of the measurement. (Note: Some of the Montana measurements associated with the NBSD likely fall into this category; S.R. Holnbeck, USGS Wyoming-Montana Water Science Center, written commun., January 2014.) Such data could be misleading for certain data analysis, and it may be of value to identify these data. Screening the PSDb-2014 for such data was beyond the scope of this investigation; however, Gao and others (1993) and Holnbeck (2011) provide guidance for identifying these types of measurements.

\section{Additional Scour Investigations}

Because the list of data sources included in this report is not exhaustive, other reports could have useful data associated with bridge sites included in the PSDb-2014. Additionally, future scour investigations could be conducted at selected bridge sites in the PSDb-2014 for the purpose of scour monitoring or additional field research that expands upon the previous studies. These future investigations could include additional bed-material characterization and more detailed scour measurements based on new and improved data-collection techniques, providing a more comprehensive dataset than that in the PSDb-2014. There are currently (2014) no plans for future updates and maintenance of the PSDb-2014, and data associated with existing studies not included in this investigation, or future studies, will likely not be incorporated in the database. However, users of the PSDb-2014 may want to consult such studies and incorporate these data into their analyses.

\section{Future Assessment Criteria}

As the understanding of stream stability and bridge scour processes evolves, it is possible that data in this report could be assessed differently. For example, changes in future assessment criteria could lead to existing data being categorized differently based on better understood scour processes, modified 
because certain parameters can be quantified more accurately, or perhaps even eliminated because a variable is no longer considered to be important. Users of the data in this report should, therefore, be aware that future assessment criteria may change how certain data are viewed.

\section{Summary}

The U.S. Geological Survey conducted a literature review to identify potential sources of published pier-scour data, and selected data were compiled into the PSDb-2014, consisting of 569 laboratory and 1,858 field measurements. These data encompass a wide range of laboratory and field conditions and represent field data from 23 States within the United States and from 6 other countries. The majority of the field measurements compiled in this effort were associated with data collected or compiled by U.S. Geological Survey personnel. Because the digital database offers a valuable resource to engineers and researchers seeking to understand the relations of pier scour in the laboratory and field, it was deemed important to publish the compiled data in a digital spreadsheet format for use by others. The digital spreadsheet is available at http://pubs.usgs.gov/ds/845.

\section{Selected References}

Alberta Transportation, 2007, Bridge inspection and maintenance system, level 2 inspection manual, version 1.1, accessed August 8, 2013, at http://www.transportation. alberta.ca/2658.htm.

Atkins, J.B., and Hedgecock, T.S., 1996, Scour at selected bridge sites in Alabama, 1991-94: U.S. Geological Survey Water-Resources Investigations Report 96-4137, 19 p.

Bata, G., and Todorovic, V., 1960, Erozija iko novosadskog mostovskog stuba (Scour around bridge piers - Novi Sad): Institut za vodoprivredu, Jaroslav Cerni, Beograd, Yugoslavia, p. 59-66, as cited in Froehlich (1988).

Benedict, S.T., and Caldwell, A.W., 2006, Development and evaluation of clear-water pier and contraction scour envelope curves in the Coastal Plain and Piedmont Provinces of South Carolina: U.S. Geological Survey Scientific Investigations Report 2005-5289, 98 p. (Also available at http:// pubs.usgs.gov/sir/2005/5289/.)

Benedict, S.T., and Caldwell, A.W., 2009, Development and evaluation of live-bed pier- and contraction-scour envelope curves in the Coastal Plain and Piedmont Provinces of South Carolina: U.S. Geological Survey Scientific Investigations Report 2009-5099, 108 p. (Also available at http://pubs.usgs.gov/sir/2009/5099/.)
Boehmler, E.M., and Olimpio, J.R., 2000, Evaluation of pierscour measurement methods and pier-scour predictions with observed scour measurements at selected bridge sites in New Hampshire, 1995-98: U.S. Geological Survey WaterResources Investigations Report 00-4183, 58 p.

Breusers, H.N.C., 1970, Discussion of local scour around bridge piers: Journal of the Hydraulic Division, American Society of Civil Engineering, v. 96, no. HY7, p. 1638-1639, as cited in Froehlich (1988).

Breusers, H.N.C., Nicollet, G., and Shen, H.W., 1977, Local scour around cylindrical piers: Journal of Hydraulic Research, v. 15, no. 3, p. 211-252, as cited in Froehlich (1988).

Butch, G.K., 1991, Measurement of bridge scour at selected sites in New York, excluding Long Island: U.S. Geological Survey Water-Resources Investigations Report 91-4083, $21 \mathrm{p}$.

Chabert, J., and Engeldinger, P., 1956, Etude des affouillements autour des Piles des ponts (Study on scour around bridge piers): Chatou, France, Laboratoire National d'Hydraulique, as cited in Sheppard and others (2011).

Chang, F.M., 1980, Scour at bridge piers; field data from Louisiana files: Federal Highway Administration Report FHWA-RD-79-105, as cited in Froehlich (1988).

Chee, R.K.W., 1982, Live-bed scour at bridge piers: Auckland, New Zealand, School of Engineering, The University of Auckland, Report No. 290, as cited in Sheppard and others (2011).

Chiew, Y.M., 1984, Local scour at bridge piers: New Zealand, School of Engineering, The University of Auckland, Report No. 355, as cited in Sheppard and others (2011).

Copp, H.D., and Johnson, J.P., 1987, Riverbed scour at bridge piers: Department of Civil and Environmental Engineering, Washington State University, WA-RD-118.1, 61 p.

Davoren, A., 1985, Local scour around a cylindrical bridge pier: Publication no. 3, Hydrology Centre, Christchurch, New Zealand, as cited in Froehlich (1988).

Dey, S., Bose, S.K., and Sastry, G.L.N., 1995, Clearwater scour at circular piers - A model: Journal of Hydraulic Engineering, American Society of Civil Engineering, v. 121, no. 12, p. 869-876, as cited in Sheppard and others (2011).

Ettema, R., 1976, Influence of bed material gradation on local scour: Auckland, New Zealand, School of Engineering, The University of Auckland, Report No. 124, as cited in Sheppard and others (2011).

Ettema, R., 1980, Scour at bridge piers: Auckland, New Zealand, School of Engineering, The University of Auckland, Report No. 216, as cited in Sheppard and others (2011). 
Ettema, R., Constantinescu, G., and Melville, B., 2011, Evaluation of bridge scour research-Pier scour processes and predictions: Transportation Research Board, National Cooperative Highway Research Program Web Document 175 (Project 24-27(01)), 195 p., accessed July 21, 2011, at http://onlinepubs.trb.org/onlinepubs/nchrp/nchrp_w175.pdf.

Ettema, R., Kirkil, G., and Muste, M., 2006, Similitude of large-scale turbulence in experiments on local scour at cylinders: Journal of Hydraulic Engineering, American Society of Civil Engineering, v. 132, no. 1, p. 33-40, as cited in Sheppard and others (2011).

Feaster, T.D., Gotvald, A.J., and Weaver, J.C., 2009, Magnitude and frequency of rural floods in the Southeastern United States, 2006 - Volume 3, South Carolina: U.S. Geological Survey Scientific Investigations Report 2009-5156, $226 \mathrm{p}$.

Froehlich, D.C., 1988, Analysis of onsite measurements of scour at piers, in Hydraulic Engineering, Proceedings of the 1988 National Conference on Hydraulic Engineering: New York, American Society of Civil Engineering, p. 534-539.

Gao, D., Posada, G.L., and Nordin, C.F., 1993, Pier scour equations used in the People's Republic of China: Washington, D.C., Federal Highway Administration report FHWASA-93-076, as cited in Sheppard and others (2011).

Graf, W.H., 1995, Load scour around piers: Lausanne, Switzerland, Laboratoire de Recherches Hydrauliques, École Polytechnique Fédérale de Lausanne, Annual Report, p. B.33.1-B.33.8, as cited in Sheppard and others (2011).

Hayes, D.C., 1996, Scour at bridge sites in Delaware, Maryland, and Virginia: U.S. Geological Survey Water-Resources Investigations Report 96-4089, 39 p.

Hodgkins, G., and Lombard, P., 2002, Observed and predicted pier scour in Maine: U.S. Geological Survey Water-Resources Investigations Report 02-4229, 30 p.

Holnbeck, S.R., 2011, Investigation of pier scour in coarse-bed streams in Montana, 2001 through 2007: U.S. Geological Survey Scientific Investigations Report 2011-5107, 68 p.

Jackson, K.S., 1997, Evaluation of bridge-scour data at selected sites in Ohio: U.S. Geological Survey WaterResources Investigations Report 97-4182, 92 p.

Jain, S.C., and Fischer, E.E., 1979, Scour around circular bridge piers at high Froude numbers: Federal Highway Administration Report FHWA-RD-79-104, available from NTIS, 5285 Port Royal Road, Springfield, Virginia 22161, as cited in Sheppard and others (2011).

Jarrett, R.D., and Boyle, J.M., 1986, Pilot study for collection of bridge-scour data: U.S. Geological Survey WaterResources Investigations Report 86-4030, 50 p.
Landers, M.N., Mueller, D.S., and Martin, G.R., 1996, Bridgescour data management system user's manual: U.S. Geological Survey Open-File Report 95-754, 75 p.

Melville, B.W., 1975, Local scour at bridge sites: Auckland, New Zealand, School of Engineering, University of Auckland, Report No. 117, as cited in Froehlich (1988).

Melville, B.W., 1984, Live bed scour at bridge piers: Journal of Hydraulic Engineering, American Society of Civil Engineers, v. 110, no. 9, p. 1234-1247.

Melville, B.W, 1997, Pier and abutment scour-Integrated Approach: Journal of Hydraulic Engineering, American Society of Civil Engineering, v. 123, no. 2, p. 125-136, as cited in Sheppard and others (2011).

Melville, B.W., and Chiew, Y.M., 1999, Time scale for local scour at bridge piers: American Society of Civil Engineering, Journal of Hydraulic Engineering, v. 125, no. 1, p. 59-65, as cited in Sheppard and others (2011).

Mueller, D.S., Landers, M.N., and Fischer, E.E, 1995, Scour measurements at bridge sites during the 1993 Upper Mississippi River Basin flood: Transportation Research Record, v. 1483 , p. $47-55$.

Mueller, D.S., Miller, R.L., and Wilson, J.T., 1994, Historical and potential scour around bridge piers and abutments of selected stream crossings in Indiana: U.S. Geological Survey Water-Resources Investigations Report 93-4066, 123 p.

Mueller, D.S., and Wagner, C.R., 2005, Field observations and evaluations of streambed scour at bridges: McLean, Virginia, Office of Engineering Research and Development, Federal Highway Administration.

Neill, C.R., 1964, Local scour around bridge piers-A comparative analysis of model experiments and field data: Highway and River Engineering Division Research Council of Alberta, $54 \mathrm{p}$.

Neill, C.R., 1965, Measurements of bridge scour and bed changes in a flooding sand-bed river, in The Institution of Civil Engineers: London, England, p. 415-435.

Norman, V.W., 1975, Scour at selected bridge sites in Alaska: U.S. Geological Survey Water-Resources Investigations Report 32-75, $160 \mathrm{p}$.

Placzek, Gary, and Haeni, F.P., 1995, Surface-geophysical techniques used to detect existing and infilled scour holes near bridge piers: U.S. Geological Survey Water-Resources Investigations Report 95-4009, 44 p.

Rantz, S.E., and others, 1982, Measurement and computation of streamflow: U.S. Geological Survey Water-Supply Paper 2175, v. 1, $631 \mathrm{p}$. 
Richardson, E.V., Harrison, L.J., Richardson, J.R., and Davis, S.R., 1991, Evaluating scour at bridges: Federal Highway Administration Hydraulic Engineering Circular No. 18, Publication No. FHWA-IP-90-017, 105 p.

Shen, H.W., 1975, Compilation of scour data based on California bridge failures: Department of Transportation Federal Highway Administration, Publication FHWA-RD-76-142, $28 \mathrm{p}$.

Shen, H.W., Schneider, V.R., and Karaki, S.S., 1969, Local scour around bridge piers: Journal of the Hydraulics Division, v. 95, no. HY6, p. 1919-1940, as cited in Sheppard and others (2011).

Sheppard, D.M., Demir, Huseyin, and Melville, Bruce, 2011, Scour at wide piers and long skewed piers: Washington, D.C., Transportation Research Board of the National Academies, NCHRP Report 682, 65 p.

Sheppard, D.M., and Miller, W., 2006, Live-bed local pier scour experiments: Journal of Hydraulic Engineering, American Society of Civil Engineering, v. 132, no. 7, p. 635-642, as cited in Sheppard and others (2011).

Sheppard, D.M., Odeh, M., and Glasser, T., 2004, Large scale clear-water local pier scour experiments: Journal of Hydraulic Engineering, American Society of Civil Engineering, v. 130 , no. 10, p. 957-963, as cited in Sheppard and others (2011).

Southard, S.E., 1992, Scour around bridge piers on stream banks in Arkansas: U.S. Geological Survey WaterResources Investigations Report 92-4126, 29 p.

Tyagi, A.K., 1987, Scour around bridge piers in Oklahoma streams: Stillwater, Oklahoma, Water Resources Engineering, Oklahoma State University, Report No. 87-1, p. 24.
U.S. Geological Survey, 2001, National bridge scour database, accessed April 15, 2014, at http://water.usgs.gov/osw/techniques/bs/BSDMS/index.htm.

Webb, D.J., Anderson, N.L., Newton, Tim, and Cardimona, Steve, 2000, Bridge scour-Application of ground penetrating radar: Federal Highway Administration and Missouri Department of Transportation special publication, accessed April 15, 2014, at http://transportation.mst.edu/media/ research/transportation/documents/scour.pdf.

Welch, L.J., and Butch, G.K., 2001, Evaluating selected scour equations for bridge piers in coarse streambeds in New York: Proceedings of the $7^{\text {th }}$ Federal Interagency Sedimentation Conference, March 25-29, 2001, Reno, Nevada, v. 1, p. I-120-I-127.

Williamson, D., 1993, Local scour measurements at bridge piers in Alberta - Proceedings of the 1993 National Conference on Hydraulic Engineering: New York, American Society of Civil Engineering, p. 534-539.

Wilson, K.V., Jr., 1995, Scour at selected bridge sites in Mississippi: U.S. Geological Survey Water-Resources Investigations Report 94-4241, 48 p.

Yanmaz, A.M., and Altinbilek, H.D., 1991, Study of timedependent local scour around bridge piers: Journal of Hydraulic Engineering, American Society of Civil Engineering, v. 117, no. 10, p. 1247-1268, as cited in Sheppard and others (2011).

Zhuravlyov, M.M., 1978, New method for estimation of local scour due to bridge piers and its substantiation: Transactions, Ministry of Transport Construction, State All Union Scientific Research Institute on Roads, Moscow, Russia, as cited in Sheppard and others (2011).

\author{
For additional information regarding this \\ publication, contact: \\ Director \\ USGS South Carolina Water Science Center \\ Stephenson Center, Suite 129 \\ 720 Gracern Road \\ Columbia, SC 29210-7651 \\ (803) 750-6181 \\ email: dc_sc@usgs.gov \\ Or visit the USGS South Carolina Water \\ Science Center Web site at: \\ http://sc.water.usgs.gov \\ Prepared by: \\ USGS Science Publishing Network \\ Raleigh Publishing Service Center \\ 3916 Sunset Ridge Road \\ Raleigh, NC 27607
}





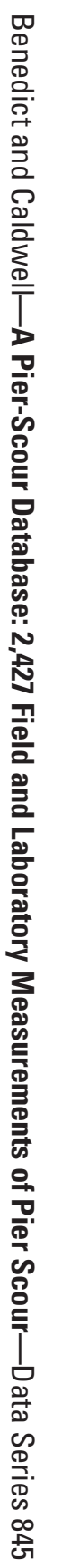

